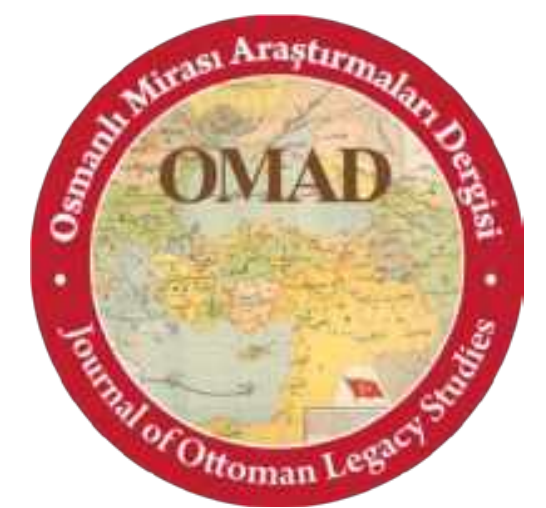

Osmanlı Mirası Araştırmaları Dergisi/Journal of Ottoman Legacy Studies

ISSN 2148-5704

www.osmanlimirasi.net

osmanlimirasi@gmail.com

Cilt 6, Sayı 14, Mart 2019/ Volume 6, Issue 14, March 2019

\title{
"IRZIMI İSTERIM": 19. YÜZYILDA CİNSEL SALDIRI DAVALARI ÜZERİNE BİR VAKA İNCELEMESİ
}

"I want my honour": A Case Study on Sexual Assault Trials in the 19th Century

Makale Türü/Article Types : Araştırma Makalesi/Research Article

Geliş Tarihi/Received Date : 08.02.2019

Kabul Tarihi/Accepted Date : 05.03.2019

Sayfa/Pages : 189-212

DOI Numarası/DOI Number : http://dx.doi.org/10.17822/omad.2019.119

\section{MELIKKE KARABACAK}

(Dr. Öğr. Üyesi), Artvin Çoruh Üniversitesi, Fen-Edebiyat Fakültesi, Tarih Bölümü, Artvin / Türkiye, e-mail: mel.sam.karabacak@gmail.com, ORCID: https:/ / orcid.org/0000-0001-65890831

\section{$\underline{\text { AtIf/Citation }}$}

Karabacak, Melike, “'Irzımı İsterim': 19. Yüzyılda Cinsel Saldırı Davaları Üzerine Bir Vaka İncelemesi”, Osmanlı Mirası Araştırmaları Dergisi, 6/14, 2019, s. 189-212.

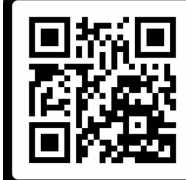

[ Scan me 



\title{
“IRZIMI İSTERIM": 19. YÜZYILDA CINSEL SALDIRI DAVALARI ÜZERINNE BİR VAKA İNCELEMESI
}

\author{
"I want my honour": A Case Study on Sexual Assault Trials in the 19th Century
}

\author{
MELIKKE KARABACAK
}

Öz: Osmanlı kadın tarihi üzerine yapılan çalışmalar mahkeme kayıtlarında çok sayıda cinsel saldırı davası olduğuna işaret etmektedir. Bu çalışmalarda tecavüz ve cinsel saldırı iddialarını mahkemeye götürmenin taşıdı̆̆ riskler tartışılmıştır. Görünen risklere rağmen kadınların neden mahkemeye gitmeyi tercih ettikleri şer'iyye sicillerinin vermiş olduğu bilgiler 1şığında anlaşılmaya çalışılmıştır. 19. yüzyılda ortaya çıkan nizamiye mahkemelerine ait kayıtlar şer'iyye sicillerinin ceza davaları konusunda okuyucuya sunduğundan çok daha fazla bilgi içermektedir. Davacı, davalı ve tanıkların sorguda vermiş olduğu ifadeler istintak raporlarına kaydedilmiştir. Osmanlı Arşivinde bulunan bu dosyalar tecavüz iddiasıyla mahkemeye giden kadınların savlarının, kendilerini savunma biçimlerinin birinci ağızdan duyulmasını sağlar. Bu çalışma 1862 yılına ait bir vakada davacının iddiaları, davalının savunması ve tanıkların ifadeleri ile mahkeme mazbatalarını esas alarak 19. yüzyılda tecavüz suçunun nasıl cezalandırıldığı konusunu ele alır. 1858 Ceza Kanunu ve takip eden yıllarda yapılan düzenlemelerle devletin cinsel saldırı suçlarını ele alış şekli ve modernleşmenin bu tür davalarda kadınların tutumuna etkisini incelemeye çalışır. mahkemesi

Anahtar Kelimeler: Osmanlı kadın tarihi, ırz davası, cinsel saldırı davası, hizmetçi kızlar, nizamiye

Abstract: The studies on the history of Ottoman women indicate that there were a large number of sexual assault cases in the court records. In these studies the risks of suing someone for rape and sexual allegations were discussed. In spite of the risks seen, it is tried to understand why women choose to go to court in the light of the knowledge given by shari'a court records. The records of the nizamî courts that appeared in the 19th century contained much more information than the shari'a court records offered to the reader about criminal cases. The statements of the plaintiff, the defendant and the witnesses were recorded in the interrogation reports. These files in the Prime Ministry Ottoman Archive allow us to hear the arguments of women from the first-hand who go to the court with the claim of rape and the ways they defend themselves. This study reviews the allegations of the plaintiff, the defence of the defendant and the testimonies of the witnesses and the records of the nizamî courts belong to a case of 1862 and focus on how the crime of rape was punished in the 19th century. Also it is going to be tried to be examined that after 1858 Criminal Code and the regulations made in following years, how did the state approach to sexual assault crimes and the effect of modernization on the attitudes of women in such cases.

Keywords: Ottoman women history, honour case, sexual assault case, servant girls, nizamî courts

\section{Giriş}

Fiziksel ve psikolojik etkileriyle cinsel suçlar arasında en ağırı olduğu kabul edilen tecavüz insanlık tarihinin rahatsız edici bir gerçeği olarak kendini gösterir. Tecavüzün kurbanı her zaman değilse de çoğu zaman kadınlar olmuştur. Tecavüz vakalarının anlamlandırılması aşamasında "tecavüz mitleri" ya da "tecavüz efsaneleri" denilen kalıp yargılar devreye girer. Kadınların baştan çıkarıcı olduğu, "hayır" derken aslında "evet" demek istedikleri, iyi kızlara tecavüz edilmeyeceği, tecavüzün aslında önemsiz bir suç olduğu gibi yargılar ${ }^{1}$ olayın kurbanı kadınların tutumlarını etkileyip sonrasında nasıl bir yol izleyeceklerini belirlemektedir. Tecavüz

\footnotetext{
${ }^{1}$ Diana Scully, Cinsel Şiddeti Anlamak Tutuklu Tecavüzcü Erkekler Üzerine Bir İnceleme, Çev. Şirin Tekeli, Laleper Aytek, Metis Yay., İstanbul 2013, s. 106, 117-128.
} 
efsaneleri bir yanda kadınların cinsel saldırı deneyimlerini anlamlandırmalarına yardımcı olurken öte yanda korkularını artırmakta ve saldırılardan kendilerini sorumlu tutmalarına sebep olmaktadır. ${ }^{2}$ Kadınlara yönelik cinsel suçlara verilen tepkiler toplum, kültür ve dinlere göre farklılık gösterir. Bir toplumun bu tür suçları nasıl değerlendireceği toplumun niteliğine, kadının toplumdaki konumuna ve meşru kabul edilen davranışlar konusundaki sınırlarına bağlıdır. Dahası toplumun cinselliğe atfettiği değerleri, inançları ve bu konularla ilgili uygulamaları zamanla değişiklik gösterebilir. Öyle ki bir dönem sadece ahlaksız diye tanımlanan davranış başka bir zamanda suç unsuru olarak görülebilmektedir. ${ }^{3}$

Tecavüz mağdurları yaşadıkları psikolojik ve fiziksel hasar üzerine toplum tarafından etiketlenmeleri sonucu ikinci bir sarsıntı yaşarlar. Yakın çevrenin verdiği tepki ve hukuki sürece dâhil olan görevlilerin şüpheci tavırları mağdurun yaşadığı saldırıyı bildirmesini engelleyecek etkiler yaratır. ${ }^{4}$ Yaşadığı travmayı ifade etme gücünü kaybeden kadının mağduriyeti perçinlenmiş olur. $\mathrm{Bu}$ sorun farklı kültür ve ülkelerde benzer şekillerde kendini gösterir. Bolivya'da tecavüz mağdurlarının adli işlemlerin yaşatacağı psikolojik ve tıbbi operasyonların vereceği fiziksel acılardan ötürü konuşmama eğilimi gösterdiği bilinir. Fatma Mernissi, Arap dünyasında kadınların seslerini yükselterek daha da güçsüz konuma düşmek yerine sorunu gizlemek yoluyla toplumsallaşmayı tercih ettiğini söyler. Edebiyatçı Seher Halifc de Filistinli kadınların toplumsal ve kültürel baskılar nedeniyle acı ve sıkıntılarını ifade etmekten kaçındıklarını belirtir. Kültürel normlar ve değerler kadınların sorunları gizlemenin en iyi yol olacağına dair kanaat geliştirmelerine neden olmuştur. ${ }^{5}$

Kadınların aile ve toplumdaki konumlarının geleneksellikten modernliğe geçişle evrimleşip daha eşitlikçi bir düzleme varacağını varsayan ve 1950 'li ve $60^{\prime}$ lı yıllarda toplumbilimlere hâkim olan modernleşme kuramının birtakım yanılgıları ilerleyen yıllarda ortaya konulmuştur. Yapılan araştırmalarda modernleşmenin beklenen sonuçları vermediği gibi cinsler arası uçurumu derinleştirdiği ve bu süreçle birlikte kadınların evvelce sahip oldukları birtakım güç ve ayrıcalıkları yitirdiği iddia edilmiştir. ${ }^{6}$ Geçmiş ile şimdi arasındaki bağlantıyı anlamaya çalışırken geçmişin gündelik iktidar ilişkilerini, bireyin sorunlar karşısında geliştirdiği stratejiyi göz önünde bulundurmak gerekir. Modernist bakış açısıyla bugünün insanı geleneğin geçmişten geldiğini kabul ederken o dönem insanlarının stratejik tavırlarını görmezden gelirse yaşananları eksik algılamış olur. Osmanlı toplumunda hukuk ve kadın ilişkisini inceleyen çalışmalar kadınların susmak yerine kanunlar ve geleneksel uygulamaları referans alarak kendi davalarını haklı çıkarmaya yarayacak stratejiler geliştirdiklerini göstermektedir. ${ }^{7}$

Şer'iyye sicillerinde buluğa erme, bekâret, karı-koca ya da cariye ilişkileri gibi özel hayata dair konularda nadiren bilgiye rastlanmakta ve bu durum ailelerin kadınlarla ilgili meseleleri mahkemeye taşımadan kendi içlerinde çözme eğilimi gösterdiklerini düşündürmektedir. ${ }^{8}$ Bu tutuma ve özel hayat üzerinde mahalleli tarafindan işletilen sıkı sosyal

\footnotetext{
2 Omca Özdemir, Bir İktidar Tekniği Olarak Kadına Yönelik Tecavüz Tehdidi, Yayımlanmamış YLT, Ankara Üniversitesi, SBE, Ankara 2010, s. 113-130.

3 Nadera Shalhoub Kevorkian, "Tecavüzün Kültürel Bir Tanımına Doğru: Filistin Toplumunda Tecavüz Mağdurlarıyla Çalışırken Karşılaşılan İkilemler”, Müslüman Toplumlarda Kadın ve Cinsellik, Der. Pınar İlkkaracan, İletişim Yay., İstanbul 2015, s. 207.

${ }^{4}$ Işı1 Çoklar, Kadına Yönelik Cinsel Şiddetin Meşrulaştırılması ve Tecavüze İlişkin Tutumlar, Yayımlanmamış YLT, Ege Üniversitesi, SBE, İzmir 2007, s. 12-13.

${ }^{5}$ Kevorkian, agm., s. 235.

${ }^{6}$ Deniz Kandiyoti, Cariyeler Bacılar Yurttaşlar Kimlikler ve Toplumsal Dönüşümler, Metis Yay., İstanbul 2015, s. 910.

${ }^{7}$ Dicle Koğacıŏlu, “Gelenek Söylemleri ve İktidarın Doğallaşması: Namus Cinayetleri Örneği”, Cogito, S. 58, 2009, s. 358.

${ }^{8}$ Dror Ze'evi, “Women in 17th Century Jerusalem: Western and Indigenous Perspectives”, Internatinal Journal of Middle East Studies (IJMES), C. 27, S. 2, Mayıs 1995, 161.
} 
kontrol mekanizmasına ${ }^{9}$ rağmen evlilik dışı gebelik, cinsel istismar, gayrimeşru çocuklar ve zina gibi suçların mahkemeye taşındığı görülmektedir. ${ }^{10}$

Osmanlı mahkeme kayıtları ve ahkâm defterleri üzerine yapılan çalışmalar bu tür vakaların en azından 16. yüzyıldan itibaren şikâyet konusu edildiğini göstermektedir. Leslie Pierce, 16. yüzyıl Ayntab mahkeme kayıtlarında cinsel sarkıntılık ve saldırı suçlarıyla açılmış davaları işaret edip mahkeme kayıtlarında yasa dışı ilişki itirafı anlamına gelen çok sayıda ifadenin varlığını ortaya koymaktadır. ${ }^{11}$ 17. yüzyıl Balıkesir sicillerini incelediği çalışmada Zübeyde G. Yağcı, sarkıntılık, laf atma, zina iftirası gibi davaların genelde kadınların kocaları ya da babaları tarafindan mahkemeye taşındığı hâlde 8 tecavüz davasından 2'si hariç diğerlerinin olayın kurbanı kadın tarafından mahkemeye götürüldüğ̈ne işaret etmektedir. ${ }^{12}$ Amira Sonbol ise 17. ve 19. yüzyıllarda Mısır'da görülen 150 davanın ya tecavüz kurbanı ya da veli veya vekilleri tarafindan mahkemeye taşındığını ifade etmektedir. ${ }^{13}$ Cinsel saldırı davalarını Osmanlı kadınlarının hangi koşullarda, yöntem ve amaçla mahkemelere taşıdığı problemi konunun anlaşılması için önemlidir. Bu çalışmada tecavüze uğradığı iddiasıyla mahkemeye giden ve iddiasını ispat etmek için çareler arayan genç bir köylü kızının kendi dilinden dökülen öyküsü ele alınarak 19. yüzyılda cinsel saldırı suçları hakkında yapılan hukuki düzenlemeler ve uygulamalar üzerine bir değerlendirme yapılmaya çalış1lacaktır.

\section{Tanzimat Öncesi Dönemde Cinsel Saldırı Suçları ve Cezalandırılması}

İslam hukuku terminolojisinde cinsel saldırı suçu için ayrı bir terim kullanılmaz. Zina terimi tarafların karşılıklı rızasıyla gayrimeşru ilişki yaşamaları anlamına gelir. Bu tecavüz anlamına gelmez ama terminolojide cinsel saldırı için zina ifadesi Osmanlı şeyhülislamları tarafından da kullanılmaya devam etmiştir. ${ }^{14}$ Zina ve zina iftirasının (kazf) da içinde yer aldığı suçlar İslam hukukunda sabit ceza gerektiren (hadd ve çoğulu hudud) suçlar olarak belirtilir. "Allah hakkı" diye tanımlanan bu cezaların pratikte affedilmesi ya da hafifletilmesi mümkün değildir. ${ }^{15}$ Kur'an'da sadece bu suçların ne şekilde cezalandırılacağı açık bir şekilde ifade edilir. Çalışmanın konusu olan tecavüz ve diğer cinsel saldırı suçları hakkında Kur'an'da açık bir ifadeye rastlanılmamaktadır. Hadis ve fikıhta ise zaman zaman aradaki farka işaret edecek ifade ve uygulamalara yer verilse de terim olarak zinadan farklı bir kelimenin kullanılmadığ 1 görülmektedir.

\footnotetext{
${ }^{9}$ Mahallelinin cinsel suçlar konusunda sosyal kontrol mekanizması olarak iki işlevi vardı. Birincisi suçlu olduğuna inandıkları kişileri genelde baskın yoluyla yakalayıp mahkemeye getirmekti. Davanın soruşturma aşamasında zanlıların genel ahlaki durumlarının mahalleliye sorulması bu mekanizmanın bir diğer yönüydü. Bkz. Nurcan Abac1, Bursa Şehri’nde Osmanlı Hukukunun Uygulanması (17. Yüzyll), T.C. Kültür Bakanlı̆̆ Yay./2778 Yayımlar Dairesi Başkanlığı Kültür Eserleri Dizisi / 328, Ankara 2001, s. 190-193. Kişinin sû-i hâl ve hüsn-i hâlinin tespitinde mahallelinin rolü ve "nâ-mahremden ictinab etmeme", "nâ-mahrem ile hatt-ı ülfet", "fuhş ve fücur ehli olma" suçlarının mahalleden ihraç kararlarına konu olması hakkında bkz. Özen Tok, "Kadı Sicilleri Işı̆̆ında Osmanlı Şehrindeki Mahalleden İhraç Kararlarında Mahalle Ahalisinin Rolü (XVII. ve XVIII. Yüzyıllarda Kayseri Örneği”, SBE Dergisi, S. 18, 2005, s. 158-162, 166. Mahrem ilişkilerin mahalleli tarafından kamusal alana taşınıp dava konusu yapılması hakkında bkz. Fikret Yılmaz, "XVI. Yüzyıl Osmanlı Toplumunda Mahremiyetin Sinırlarına Dair”, Toplum ve Bilim, S. 83, Kış 1999 / 2000, ss. 92-110. Mahalleli ve köy halkının kişileri kontrol etme ve suçluları ihbar etme yetkisi dışında bunların yaşadıkları yerden ihracını talep hakları da vardı (Zübeyde G. Yağcı, "Osmanlı Taşrasında Kadınlara Yönelik Cinsel Suçlarda Adalet Arama Geleneği”, Kadın Araştırmaları Dergisi, 6/2, Aralık, 2005, s. 56).

${ }^{10}$ Abraham Marcus, "Privacy in Eighteenth Century Aleppo: The Limits of Cultural Ideals”, IJMES, C. 18, S. 2, May1s 1986, s. 169.

${ }^{11}$ Leslie Pierce, Ahlak Oyunları 1540-1541 Osmanlı'da Ayıntab Mahkemesi ve Toplumsal Cinsiyet, Çev. Ülkü Tansel, Tarih Vakfi Yurt Yay., İstanbul 2005, s. 476.

${ }^{12}$ Zübeyde Güneş Yağcı, “Adalet Arama Geleneği”, s. 61.

${ }^{13}$ Amira Sonbol, "Osmanlı Misır'1 ve Modern Misır'da Tecavüz ve Hukuk”, Modernleşmenin Eşiğinde Osmanlı Kadınları, Ed. Madeline Zilfi, Cev. Necmiye Alpay, Tarih Vakfi Yurt Yay., İstanbul 2010, s. 220.

${ }^{14}$ Colin Imber, Studies in Ottoman History and Law, The Isis Press, İstanbul 1996, s. 203.

${ }^{15}$ Imber, Seriattan Kanuna Ebussuud ve Osmanlı'da İslami Hukuk, Çev. Murteza Bedir, Tarih Vakfi Yurt Yay., İstanbul 2004, s. 219.
} 
Kur'an'da Nur suresinde zina eden kişiye bedenî ceza olarak 100 kırbaç (celde) verileceği ifade olunmaktadır. Hz. Muhammed döneminde ise zina edenin evli olup olmadığının önemine dikkat çekilerek 100 kırbaç suçunun bekârlar için geçerli olduğuna, evli olup da zina eden kadın ya da erkeğe recm cezası verileceğine hükmedilmiştir. Bekârın cezalandırılmasında kırbaç cezasıyla birlikte yaşadığı yerden 1 yıllığına sürgün edilmesi eklenmiştir. ${ }^{16}$ Bir hadiste geçen olayda adam Hz. Muhammed'e giderek zina işlediğini itiraf etmiştir. Hz Muhammed adama birkaç kez kadının rıza gösterip göstermediğini sormuş, adam da her seferinde kadının rızası olmadığını söyleyince Hz. Muhammed kadının serbest bırakılmasına adamın ise idamına karar vermiştir. Başka bir hadiste geçen olayda kadın zinaya rıza gösterdiğini itiraf ettiğinden recm edilmiştir. ${ }^{17}$ Irza geçme suçunu âdet hâline getirene ise siyaseten katl cezası verilmiştir. ${ }^{18}$

Hz. Muhammed sonrası dönemde tecavüzün cezalandırılmasına farklı yorumlar getirilmiştir. Osmanlı şeyhülislamları tarafından hukuk el kitabı olarak kullanılan Mülteka'nın yazarı 16. yüzyıl hukuk bilgini İbrahim el-Halebi Kur'an'da zina için öngörülen karşılıklı razı olma ilkesine uymadığ 1 için 1rza geçmeyi Allah hakkına karşı değil şahsa karşı işlenmiş bir suç olarak değerlendirmektedir. ${ }^{19}$ Osmanlı şeyhülislamları ceza hukuku alanında fetvalarını fikıh el kitapları, örfi hukuk ve daha önceden verilmiş yargı kararlarını esas alarak verirlerdi. Kanuni dönemi şeyhülislamı Ebussuud Efendi'nin fetvalarında zor kullanarak cinsel ilişkiye girmek hakkında hükümler bulunmaktadır. Bunlardan birinde evli bir erkeğin nikâhında olmayan bir kadına zorla sahip olması durumunda adamın katledilmesi gerektiğini belirtmiştir. Diğerinde ise bir kadın evine girip zorla kendisine sahip olmaya çalışan bir adamı başka bir çaresi olmadığı takdirde balta ile yaralayıp öldürdügü hâlde cezadan muaf olup gazâ etmiş kabul edileceği ifade edilmiştir. ${ }^{20}$ Fetva metinlerinde zinanın cebr (zor) ile gerçekleşmesi durumunda farklı cezalandırılacağı açıç̧a gösterilmiştir. Ebussuud Efendi de zina ve tecavüz arasındaki farkı kabul etmekle birlikte fetvalarında cinsel saldırı için zina terimini kullanmaya devam etmiştir. ${ }^{21}$

Fetva metinlerinde tecavüz için "cebren zina" ifadesi kullanılmakla birlikte mahkeme kayıtlarında zina sözcüğünün yerini genelde “fi'l-i şenı̂”nin aldığı görülür. Sözlük anlamı kötü davranış olan fi'l-i şenî bazen zina ve bazen de tecavüz anlamında kullanılabiliyordu. Bu kullanımlar sicilin ait olduğu yöreye ve döneme göre farklılıklar gösterebilmektedir. Pierce 16. yüzyıl Ayntab sicillerinde fi'l-i şenî ifadesinin hiç geçmediğini tecavüz için "cebren zina" teriminin kullanıldığını söylerken Tuğ, 18. yüzyıl Ankara ve Bursa sicillerinde genelde fi'l-i şenî teriminin kullanıldığını belirtir. Olayın ayrıntısı sicil kayıtlarında verilmese de mutlaka zor ile gerçekleştiğine dair "cebren fi'l-i şen̂̀", "fi'l-i şenî kastıyla taarruz”, "bikrini izale kastıyla taarruz" gibi açıklayıcı ifadelere yer verildiği görülmüştür. ${ }^{22}$

Osmanlı kanunnamelerinde kadın veya oğlan kaçırma, zina kastıyla bir eve girme, sarkıntılık, dokunma, gözle ya da sözle taciz gibi birçok cinsel saldırı suçlanına yer veriliir ${ }^{23}$ ancak tecavüz hakkında doğrudan bir şey söylenmez ve bu konu zina kapsamında kalmaya

\footnotetext{
${ }^{16}$ Ömer Menekşe, “Osmanlı'da Zina Cezası Olarak Recm”, Marife, Yı1 3, S. 2, Güz 2003, s. 8; Abdülmecit Mutaf, "Teorik ve Pratik Olarak Osmanlı'da Recm Cezası Bazı Batı Anadolu Şehirlerindeki Uygulamalar", Turkish Studies, 3/ 4 Yaz 2008, s. 576; Fikret Yılmaz, "Zina ve Fuhuş Arasında Kalanlar Fahişe, Subaşıya Karşı", Toplumsal Tarih, S. 220, Nisan 2012, s. 26-27.

${ }^{17}$ Amira Sonbol, agm., s. 212-213.

${ }^{18}$ Mustafa Avc1, Osmanlı Hukukunda Suçlar ve Cezalar, Gökkubbe Yay., İstanbul 2004, s. 171.

${ }^{19}$ Leslie Pierce, age., s. 119.

${ }^{20}$ M. Ertuğrul Düzdağ, Şeyhülislâm Ebussuud Efendi'nin Fetvalarına Göre Kanuni Devrinde Osmanlı Hayatı, Kap1 Yay., İstanbul 2012, s. 203

${ }^{21}$ Imber, Ottoman History and Law, , s. 203.

${ }^{22}$ Başak Tuğ, Politics of Honor: The Institutional and Social Frontiers of "Illicit" Sex in Mid-Eighteenth Century Ottoman Anatolia Yayımlanmamıs DT, New York Üniversitesi, 2009, s. 191-195.

${ }^{23}$ Zübeyde G. Yağcı, "Osmanlı Kanunnamelerinde Suç ve Ceza", Tanzimat Öncesi Osmanlı Toplumunda Cinsiyet, Mahremiyet ve Sosyal Hayat, Ed. Miyase Koyuncu Kaya, Bedriye Yılmaz, Türkiye Diyanet Vakfı Yay., Ankara 2018, s. 421-431.
} 
devam eder. ${ }^{24}$ Fatih Kanunnamesi’nde birinin evine zina kastıyla girmek olarak tanımlanan suç cinsel saldırı kapsamında değerlendirilecek bir anlam taşımaktadır. Bu suçu işleyen kişiye evli ve zengin ise 300, evli orta hâlli ise 200, evli fakir ise 100, evli ve çok fakir ise 50 akçe para cezası verileceği belirtilmektedir. Suçlu ergen ve zengin ise 100, orta hâlli ise 50, fakir ise 40, çok fakir ise 30 akçe para ödemekle cezalandırılacaktır. ${ }^{25}$ Aynı kanunnamede başkasının karısına sarkıntılık yapanın kadının takdiriyle taziren cezalandırılacağı, para cezasının ağaç başına 1 akçe olarak verileceği belirtilmiştir. ${ }^{26}$ Fatih Kanunnamesi'nde cinsel suçlarla ilgili yer alan hükümler hemen hemen Tanzimat devrine kadar çok az değişiklikle yerini korumuştur. Kendinden sonraki dönemlerde metot ve mantık aynı kalmak üzere cinsel suçlar hakkında daha detaylı düzenlemeler yapıldı ğı görülmektedir. ${ }^{27}$

II. Bayezid Kanunnamesi'nde birinin evine zina kastıyla girme, kız ve oğlan kaçırma gibi cinsel suçlar kapsamına girebilecek eylemler ele alınmıştır. Kanunnamede " $\mathrm{Klz}$ oğlan çeken kişinin ve hiyânet ile bir ecnebinin evine giren kimsenin ve avret ve klz çekmeğe varan kimesnenin içmeği (emceği) kesile. Klz ve avret çeküp gücile nikâh etdirene cebr ile boşadalar ve nikâh edenin sakalın keseler ve muhkem let edeler" denilerek bu suçlara bedensel cezalar verileceği belirtilmiştir. ${ }^{28}$ Kanuni Sultan Süleyman Kanunnamesi’nde "Ĕger bir kişi avret veya kız kapsa, avretin ve kizin rizasi olmasa erin zekeri keseler. Avrete, kiza nesne demiyeler ve cürm almayalar. Ĕger avret veya $\mathrm{klz}$ razı olup evinden dışarı gitseler onların ferçlerini dağlayalar" denilerek kadın ve kız kaçırmaya rızanın olup olmamasına göre farklı ancak yine bedenî cezalar verilmiştir. ${ }^{29}$ Uygulamada ise kız kaçırmaya bedenî ceza yerine kürek cezası gibi tazir cinsinden cezalar verildiği bilinmektedir. ${ }^{30}$ Kanuni dönemi öncesi kanunnamelerde sözlü sarkıntılık için ceza tespit edilmiş buna ek olarak bu dönem kanunnamesinde cinsel tacizin de cezası tespit edilip taziren cezalandırılmak dışında suçlunun bir de hapsedileceği ifade edilmiştir. ${ }^{31}$

Hukuk metinleri ve uygulamalara bakıldığında Tanzimat öncesi dönemde cinsel saldırı suçlarının hakk-1 âdemî (kul hakkı) yani kişiye yapılmış kötülük, ona verilmiş zarar ile hakk-1 Allah (Allah hakkı) yani Allah'a ve bunun bir uzantısı olarak topluma karşı işlenmiş suçlar arasında bir noktada değerlendirildiği görülmektedir. Cinsel saldırılarda kurbanın kendisinin mahkemeye gidip davayı başlatması konunun şahıs hukukuna girdiğine bir işarettir ve bu özelliği onu zinadan ayırmaktadır. Çünkü zina gibi Allah'a karşı işlenmiş suçlar imam ya da muhtarın şikâyetiyle subaşı tarafından mahkemeye taşınırdı. Sonraki aşamalarda idarecilerin davaya müdahil olmaları ise cinsel saldırı davalarının kamu hukukuna giren yönünü oluşturmaktadır. ${ }^{32}$

Şer'iyye sicillerinde tecavüz davalarına yer verilmekle birlikte suçun nasıl cezalandırıldığı her zaman çok açık olarak ifade edilmeyebiliyordu. Bir köylü kızı tecavüze uğrayıp zorla bekâretinin alındığı iddiasıyla mahkemeye gidip zanlı suçunu ikrar ettiğinde mahkeme tecavüzcünün şer'an cezalandırılmasına hükmedebiliyordu. ${ }^{33}$ Ancak bu şer'î cezanın

\footnotetext{
${ }^{24}$ Imber, Ottoman History and Law, s. 187.

${ }^{25}$ Cihan Osmanoğlu, "Klasik Dönem Osmanlı Hukukunda Zina Suçu ve Cezası", İ̈HFM, C. 66, S. 1, s. 126.

${ }^{26}$ Osmanoğlu, a.g.m, s. 131.

${ }^{27}$ İsmail Avc1, "Osmanlılarda Zina Suçu ve Cezası", Türkler, C. X, s. 152.

${ }^{28}$ Osmanoğlu, agm. s. 133-35.

${ }^{29}$ Uriel Heyd, Studies in Old Ottoman Criminal Law, Clarendon Press, Oxford 1973, s.59, 98.

${ }^{30}$ Mustafa Avc1, age., s. 204.

31 "Bir kişi avretin yoluna varup yahud evine girip saçın çekse veya donun veya destarın alsa, bade's-sübut muhkem ta'zir edüp dahi haps edüp Dergâh-ı Muallaya arz edeler." "Ĕ̆er bir kişi bir kişinin cariyesine söylese veya öpse, muhkem ta'zir olunup iki ağaca bir cürm alına”. ( Avc1, agm., s. 152.)

32 Pierce, age., s. 174-175. Pierce bu tespiti 16. yüzyıl için yapar ancak konu hakkında 17. yüzyıl için yapılan çalışmalar da bu tespiti destekler. Abacı, age., s. 190-195; Yağcı, agm., s. 12. Söz konusu çalışmalarda zinanın yerel yöneticiler tarafından mahkemeye taşındığı hâlde cinsel saldırıların kurban ya da eşi veya babası tarafından mahkemeye getirildiğini gösterir sicil kayıtları görünür.

${ }^{33}$ Belkıs Konan, "Osmanlı Hukukunda Tecavüz Suçu”, OTAM, 29, Bahar 2011, s. 161.
} 
ne olacağı sicile yazılmayabiliyordu. Bazı kayıtlarda ise cezanın içeriğine dair daha açık ifadelere yer verilmektedir. Kız kaçırıp alıkoyma suçunu işleyen aynı zamanda eşkıyalığa da karışmış bir kişi ise cezalandırma siyaseten katle kadar varabiliyordu. "ehl-i fesad taifesinden" kişiler hakkında cinsel saldırı suçu işlediklerinde katledilmelerine dair hüküm çıkabiliyordu. ${ }^{35}$ Suçunu itiraf edip eşkıyalık, hırsızlık gibi başka bir suçu olmayan sanıklara 17. ve 18 . yüzyıllarda sürgün ve kalebentlik gibi tazir cezasının verildiğine dair örnekler vardır. ${ }^{36}$

Zinayı çok aşağı bir suç olarak kabul eden İslam hukuku bu suçun ispatını da çok ağır şartlara bağlamıştır. Zinanın sübut bulması için diğer suçlarda iki şahidin tanıklığ 1 yeterli görülürken burada dört şahidin bizzat olaya görgü tanıklı̆̆ı etmesi, zina ikrarının ise ayrı ayrı dört mecliste yapılması gerekirdi. ${ }^{37}$ Mahkemeler cinsel saldırı suçlarının kovuşturulmasını dörtten az tanığın ifadesini, ikinci dereceden kanıtları ve söylentileri kabul ederek zinanın kovuşturma şartlarına göre yumuşatmıştır. ${ }^{38} 17$. yüzyılda Gizzeli bir kadın kendisine tecavüz ettiği adamdan şikâyetçi olduğunda zanlı suçlamayı reddettiği hâlde kadın adamın kendisine saldırdığını gören tanıklar getirip adamın tazminat ödemesini ve kırbaç cezası almasını sağlamıştır. ${ }^{39}$ Yine 17. yüzyılda bu sefer Ankara'ya bağlı bir köyde Cennet isimli kadın iki kişi tarafından tecavüze uğradığını iddia ettiğinde başlangıçta zanlılar iddiayı reddetseler de köy ahalisinden dört erkeğin şahitliğiyle iddiasını doğrulayabilmiştir. Bu tanıklar olayın gerçekleşme anının görgü tanı̆̆ı değillerdi, ancak sanıkları kadının evine girerken görmüşler ve evden feryatların yükseldiğini işitmişlerdi. ${ }^{40}$

Cinsel saldırı davalarına yön veren ikinci yargılama ilkesi kişilerin namuslu olarak tanınmaları, daha önceden hiçbir cinsel ahlaksızlık şüphe ya da suçlamasını üzerine çekmemiş olması yani töhmetli olmamak ilkesiydi. ${ }^{41}$ Şöhretin yaşamsal bir öneme sahip olduğu Osmanlı sosyal hukuk düzeninde ahlak dışı bir davranışta bulunmak iddiasıyla töhmet altında bırakılan şahıs ileride karşılaşacağ 1 ceza davalarında olağan suçlu olarak görülebilirdi. ${ }^{42} 17$. yüzyıl sicillerinde müslim ve gayrimüslim Balıkesir kadınları bizzat kendileri ya da koca veya babalarının vekâletinde mahkemeye giderek iyi hâllerinin soruşturulmasını talep edip töhmetli olmaktan kurtulmak istemişlerdir. Görülen 62 davanın 46'sı kadınlar lehine sonuçlanmıştır. ${ }^{43}$ Cinsel saldırı iddiaları mahkemeye taşındığında davalı suçunu ikrar etmeyip davacı da iddiasını ispat edemediğinde bu sefer her iki tarafin "sû-i hâl" ve "hüsn-i hâli" ahalinin ileri gelenlerinden soruşturuluyor ve doğrudan kararı etkileyen sonuçlara varılıyordu. Mahalleli kadın hakkında "kendi hâlinde dindar ve müstakime hatundur" gibi lehte tanıklık edebildiği gibi ahlak düzenini bozduğu iddiasıyla "nâ-mahremden ictinab etmeme, nâ-mahrem ile halt-ı ülfet, fuhş ve fücur ehli olma" ş̧eklinde tanımladıkları kişinin de mahalleden ihracına sebep olabiliyorlard $1 .{ }^{44}$

Tecavüz davalarında elbette sanığın kimliği de kararı hatta cezanın şiddetini etkilemiştir. Özellikle "eşkıya" diye tanımlanan sanıkların bazen idamla bazen de 5 yıla varan kürek

\footnotetext{
${ }^{34}$ Abac1, agm., s. 194.

${ }^{35}$ Arşiv Belgelerine Göre Osmanlı'da Kadın, T.C. Başbakanlık Devlet Arşivleri Genel Müdürlüğü Osmanlı Arşivi Daire Başkanlığı, İstanbul 2015, s. 218.

${ }^{36}$ Neşe Erim, “Osmanlı İmparatorluğunda Kalebentlik Cezası ve Suçların Sınıflandırılması Üzerine Bir Deneme”, Osmanlı Araştırmaları IV, Ed. Halil İnalcık, Nejat Göyünç, Health W. Lowry, İstanbul 1984, s. 83; Yağc1, agm., s. 61.

${ }^{37}$ Joseph Schacht, İslam Hukukuna Giriş, Çev. Mehmet Dağ, Abdulkadir Şener, Ankara 1986, s. 182.

${ }^{38}$ Pierce, age., s. 175.

${ }^{39}$ Amira Sonbol, "Osmanlı Misır'ı ve Modern Misır'da Tecavüz”, s. 216.

${ }^{40}$ Belkıs Konan, "Osmanlı Hukukunda Tecavüz Suçu”, s. 159.

${ }^{41}$ Pierce, age., s. 176.

${ }^{42}$ Pierce, age., s. 8.

${ }^{43}$ Yağc1, "Osmanlı Taşrasında", s. 64.

44 Özen Tok, "Kadı Sicilleri Işı̆̆ında Osmanlı Şehrindeki Mahalleden İhraç Kararlarında Mahalle Ahalisinin Rolü (XVII. ve XVIII. Yüzy1llarda Kayseri Örneği), SBE Dergisi, 18, 2005, s. 166.
} 
cezasıyla cezalandırıldıkları görülmüştür. ${ }^{45} 1671$ 'de Ayşe isimli kadın mahkemeye başvurarak 3 adamın zorla evine girip kendisine tecavüz ettiklerini iddia ettiğinde mahalleli sanıkların düzgün adamlar olmadığını, herkese rahatsızlık verdiklerini söylemişlerdir. Mahkeme bu ifadelere bağlı olarak sanıkların şer'an cezalandırılmalarına hükmetmiştir. ${ }^{46}$ Bu şekilde sû-i hâllerine şahitlik edilen sanıkların kalebentlik ve kürek gibi tazir cezalarına çarptırıldıkları görülmüştür. $\mathrm{Bu}$ türden suçluların küreğe konulması donanmanın ihtiyacını karşılamak için başvurulan bir yöntem olarak değerlendirilmiştir. ${ }^{47}$ Ahalinin ileri gelenleri sanık lehinde şahitlik yaptıklarında ise kadının davayı kazanmak için hiçbir şansı kalmıyordu. 18. yüzyıl Selânik sicillerinde görülen bir davada Hasan'ın, ırzına geçerek bekâretini aldığını iddia eden Fatma'nın suçlamaya dair elinde bir kanıtı bulunmamaktaydı. Kadı, Hasan hakkında yörenin ileri gelenleri arasında bir soruşturma yapmış, onlar da adamın salih, mütedeyyin bir kişi olduğunu söyleyip fi'lli şenî yapacak bir kişi olmadığı yönünde ifade verince mahkeme sanık Hasan lehinde sonuçlanmıştır. ${ }^{48}$

İslam hukukunda Allah'a karşı işlenen suçlar kapsamında yer alan kazf (zina iftirası) ile hem kişi onuru ve iffeti hem de kamu ahlakının korunması benimsenmiştir. Kur'an'da hürlerin 80, kölelerin 40 sopa ile cezalandırılacağı belirtilen kazf suçu kişinin tanıklık ehliyetinin kaybı anlamına geliyordu. ${ }^{49}$ Osmanlı kanunnamelerinde de kazf suçu hem erkek hem de kadın için düzenlenmiştir. Fatih Kanunnamesi'nde zina isnadında bulunulan kadın ya da erkek bunu inkâr edip yemin ederse suçlayanın taziren cezalandırılması ve 2 ağaca bir akçe para cezası verilmesi gerektiği öngörülmektedir. Bu madde değişikliğe uğramadan II. Bayezid ve Yavuz Selim Kanunnamelerinde de yer almıştır. Kanuni Sultan Süleyman Kanunnamesi'nde bu maddeler aynen korunmakla birlikte kadın zina isnadında bulunduğunda erkeğin inkâr ederek yemininin kabul edilmesi durumunda kadın tarafın şahit gösterememesi şartı konulmuştur. Zira İslam hukukuna göre kazf suçunun ortaya çıkması için suç isnadında bulunan kişinin iddiasını doğrulayacak dört şahit göstermesi gerekmektedir. Sanığın yemini ancak tanıklar olmadığında geçerli olabilmekteydi. ${ }^{50}$

Cinsel saldırıya uğradığı iddiasıyla mahkemeye gidip iddiasını kanıtlayamadığı ve mahallelinin de kadının lehinde iyi hâl şahitliği yapmadığı durumlarda kadının kazf suçu ile itham edilme riski bulunuyordu. Ancak elimizde bulunan örnekler kadınların iddialarını ispat edemeseler de kazf ile suçlanmadıklarını göstermektedir. 17. yüzyılda Balıkesir'in Çinge köyünde gerçekleşen olayda Ümmü isimli kadın, İsmail Beşe'nin kendisine tecavüz ettiği iddiasıyla mahkemeye gitmiş, isnadı destekleyecek şahitler getirememiş ve sonuç olarak İsmail'e herhangi bir ceza verilmemiştir. Ümmü üstelik 8 aylık hamiledir. Bu açıktan bir zina itirafı olduğu hâlde mahkeme kadına herhangi bir kavgaya girmemesi ve İsmail Beşe’den uzak durmasını tembih etmiştir. ${ }^{51} 17$. yüzyılda Kahire'de gerçekleşen vakada ise tecavüzle suçlanan adam isnadı reddetmiş, kadın tecavüz için tanık gösterememiş ve sanık kadının ahlaksız biri olduğuna dair mahkemeye şahitler getirmiştir. Mahkeme kadını suçlu bulmuş ve bu sefer sanığın talebi üzerine kadına sürgün cezası verilmiştir. ${ }^{52}$ Sanı̆̆ın sosyal statü olarak davacı kadından üstün durumda olması ona mahkemeye kadının aleyhinde ve kendi lehinde şahitlik

\footnotetext{
${ }^{45}$ Yağcı, "Osmanlı Taşrasında”, s. 60-61.

${ }^{46}$ Konan, agm., s. 59.

47 Yağcı, "Osmanlı Kanunnamelerinde Suç ve Ceza", s. 423-424. 16. yüzyılda tecavüz suçlularına hırsızlık, kumarbazlık ve zina suçluları gibi kürek cezasının verildiği bilinmektedir: Mehmet İpşirli, "XVI. Yüzyılın İkinci Yarısında Kürek Cezası İle İlgili Hükümler”, İstanbul Üniversitesi Edebiyat Fakültesi Tarih Enstitüsü Dergisi Prof. Tayyip Gökbilgin Hatıra Sayısı, S. 12, s. 203-248.

${ }^{48}$ Eyal Ginio, "Women, Domestic Violence and Breaking Silince: The Evidence of the Şeriat Court of EighteenthCentury Salonica”,Mélanges en I'Honneur du Prof. Dr. Suraiya Faroqhi, ed. Abdeljelil Temimi, Publications de la Fondation Temimi pour la Recherche Scientifique et I’Information, Tunus 2008, s. 157.

${ }^{49}$ Avc1, Osmanlı Hukukunda Suçlar ve Cezalar, s. 214, 230.

${ }^{50}$ Yağcı, "Suç ve Ceza", s. 438-439.

${ }^{51}$ Yağc1, "Osmanlı Taşrasında", s. 58.

52 Sonbol, agm., s. 216-217.
} 
yapacak kişiler getirmesini mümkün kılabilmektedir. Sombol bu durumu kadıların taraflar arasındaki sosyal statü farklarını göz önüne alarak ya da kadın iddiasını ispat edemese de hikâyesini inandırıcı bulmaları durumunda onlara bir ceza vermekten imtina ettikleri şeklinde yorumlamıştır. ${ }^{53}$ Ancak mahkeme kayıtları ayrıntılı sorgulamayı ve kadıların hangi saiklerle karar verdiği bilgisini ihtiva etmediği için bu tür yorumların yanlış genellemelere sebep olabileceğini belirtmek gerekir.

Mahkemeler dava sonucu aleyhinde çıksa da özellikle alt sınıf ve köylü kadınlar için seslerini duyurmak ve onurlarını kurtarmak adına bir firsat veriyordu. ${ }^{54}$ Kadınlar ceza almak ya da lekelenmiş olmak riskine rağmen namusunu temizlemenin bir yolu olarak mahkemeye gitmeyi tercih etmişlerdir. Kadınlar uğradığı saldırının kayıtlara geçmesini sağlarken olayın kovuşturulmasını sağlamakla kalmayıp yaşadığı toplumdaki insanların nazarında ahlaki duruşunu da korumaya çalışmıştır. Mahkemeler bu anlamda kadınlara masumiyetini kamusal alanda duyurma firsatını yaratan bir mecra olarak işlev görmüşlerdir. ${ }^{55}$ Bunun dışında mahkemeler sadece hukuk metinleri ve kanunları göz önünde bulundurarak karar vermekle kalmamış yöre halkının anlaşmazlıklarının sulh edilmesinin de bir parçası olmuşlardır. Kastamonu şer'iyye sicilleri üzerine yapılan bir çalışma; yöre kadınlarının ırza geçme davalarını mahkemeye taşırken mütecavizle evlenmek, doğacak çocuğuna nafaka sağlamak ya da tazminat almak gibi bir anlaşmaya varmak üzere yollar aradıklarını ortaya koymaktadır. ${ }^{56}$

Hanefi mezhebi, mütecavizin kurban ile evlenmesi durumunda cezanın hafifletilmesinin yolunu açmış, şikâyetin geri çekilmesi şartıyla cezanın bir çekişme konusu olmaktan çıkmasını sağlamıştır. ${ }^{57}$ Sicillerde davacı kadının sonradan davasını çektiğini gösterir örnekler bulunmaktadır. $\mathrm{Bu}$ tür durumlar bir tazminat üzerine anlaşılmış olması olasıllğını akıllara getirir. ${ }^{58}$ Sicillerde sanığın tazminat ödemesi durumunda davanın sonlanmasına dair örnekler de görülmektedir. 1742'de Mısır'da gerçekleşen olayda reşit olmayan bakire bir kızın tecavüze uğradığı iddiası babası tarafından mahkemeye taşınmıştır. Sanık iddiayı reddetse de kabile (ebe) kadınlar tarafından yapılan muayenenin sonucu davacıların iddiasını onaylar yönde çıkmış, bekâreti yitirmenin karşılığı mahkeme tarafından hesaplanmıştır. Sanık bu meblağı ödedikten sonra baba davasını geri çekmiş, adam da serbest bırakılmıştır. ${ }^{59}$

\section{Tanzimat Sonrası Cinsel Saldırı Davaları: Bir Vaka Analizi}

Sosyal tarih çalışmaları için vazgeçilemez bir öneme sahip olan şer'iyye sicilleri diğer davalara nazaran ceza davalarına daha az yer vermektedir. Bu durumun bir sebebi şer’̂̂ mahkemelerin sadece yargı görevi yapmayıp aynı zamanda idari, beledî ve noterlikle de ilgili işleri görmesidir. Şer'̂̂ mahkemelere ait kayıtlarda olayların nedeni ya da arka plandaki hikâyenin ne olduğu gibi ayrıntılar genellikle yazılmamıştır. Bu durumda da cinayet ya da tecavüz kovuşturmaları ya da özel mülke saldırı gibi pek çok ceza davasında okuyucu olay örüntüsünü oluşturacak bilgiyi mahkeme kayıtlarında bulamamaktadır. Suçlunun soruşturulmasına dair şer'iyye sicillerinde bir iz olmadığı gibi pek çok ceza davasında mahkemenin verdiği kararın da kayıtlara geçmediği gözlenmektedir. ${ }^{60}$

Tanzimat Dönemi'nde Osmanlı yargı sisteminde meydana gelen değişmeler ve taşra meclislerinin kuruluşunu takip eden süreçte ortaya çıan nizamiye mahkemelerine ait kayıtlar

\footnotetext{
53 Sonbol, agm., s. 219.

${ }^{54}$ Pierce, age., s. 492-493.

${ }_{55}$ Marc David Baer, At Meydanında Ölüm 17. Yüzyll İstanbul'unda Toplumsal Cinsiyet, Hoşgörü ve İhtida, Çev. Pınar Yanardağ, Koç Üniversitesi Yay., İstanbul 2016, s. 101-102.

56 Boğaç A. Ergene, "Why Did Ümmü Gülsüm Go to Court? Ottoman Legal Practice between History and Antropology”, Islamic Law and Society, 17, 2010, s. 215-244.

${ }^{57}$ Sonbol, agm., s.214, 220.

${ }^{58}$ Konan, agm., s. 160.

${ }^{59}$ Sonbol, agm., s. 215, 218.

60 Dror Ze'evi, “The Use of Ottoman Shari'a Court Records as a Source of Middle Eastern Social History: A Reappraisal”, Islamic Law and Society, 5/1, 1998, s. 48.
} 
şer'iyye sicillerinin bu eksiklerini karşılayan bilgileri ihtiva etmektedir. Diğer hiçbir Osmanlı hukuk kaynağında görülmeyen bir yönüyle istintak raporları okuyucuya davanın soruşturulması aşamasını ayrıntılı bir şekilde vermektedir. Bu belgeler "cahil", elit dışı sosyal aktörlerin davalı, davacı, şahit olarak verdikleri ifadeleri birincil ağızdan bize ulaştırmaktadır. Bu özelliğiyle istintak raporları olayın aktörlerinin düşünsel ve ahlaksal dünyalarını anlamaya yönelik bilgiler sunar. ${ }^{61}$

1862 yılına ait nizamiye mahkemesi kayıtları Filibe'nin Pazarcık kazasına bağlı Çerova köyünden 18 yaşında Petkane isimli kızın ırz davasının bütün aşamalarını, şahısların birincil ağızdan ifadeleriyle takip etme imkânı vermektedir. ${ }^{62}$ Dosya içinde davacı Petkane ve davalı Rıza'nın Pazarcık Kaza Meclisinde ve Filibe Liva Meclisinde yapılan sorgularına dair tutanakları, tanık Hristo'nun kaza meclisindeki sorgu tutanağı ile mahkeme mazbataları yer almaktadır.

\section{Davacı Petkane, 18 Yaşında, Hizmetçi}

Filibe'nin Çerova köyünden 18 yaşındaki Marko kızı Petkane'nin ifadesine göre kendisi zorla köyünden alınıp getirildiği davacı olduğu Rıza'nın evinde 1,5 yıldır hizmetkârlık yapmaktadır. ${ }^{63}$

Hizmetçilik genellikle Batılılaşmayla ve köleliğin ilgasıyla ilgili değerlendirilerek 19. yüzyılın ikinci yarısında ortaya çıkmış bir meslek olarak görülmektedir. ${ }^{64} 19$. yüzyıl Osmanlı toplumunda ücretli hizmetçilik köleliğin kaldırılmasına bağlı olarak artmış olsa da köle kullanımından bağımsız ve özellikle de 15. yüzyılda gayrimüslimlerin köle edinmelerine getirilen yasağa bağlı olarak varlık gösterdiği bilinmektedir. ${ }^{65}$ Lucy M. Garnett, Bluntların yanında yaklaşık 13 yıl hizmetçilik yapan Bulgar Maria'yı tanımlarken çok yoksul ailelere mensup bazı Bulgar kızlarının ev içi hizmetlerde çalıştığını, bu işi yapan kızların çalıştıkları aileye kendilerini adayıp son derece vefakâr olduklarını ifade etmektedir. Doğudaki diğer hizmetçiler gibi Maria da sahipleri tarafından giydiriliyor ihtiyaçları karşılanıyordu. Maria aylık ücretini almıyor ölümünde miras olarak yine evin küçük oğluna verilmesini vasiyet ediyordu. ${ }^{66}$ Garnett, bu açıklamayla muhtemelen Doğudaki hizmetçiliğin Batıdakinden kültürel anlamda farkına işaret etmek istemiş, hizmetçiliği daha çok beslemelik ya da ahretlik gibi isimlerle tanımlanan duruma yakınlaştırmıştır. Nitekim Redhouse'da beslemelik " $k l z$ ya da kadın hizmetçi, evde hayır için beslenen çocuk" diye tanımlanmaktadır. ${ }^{67}$ Osmanlı toplumunda yoksul ailelerin genellikle kız çocuklarını belli bir ücret karşı1ığında varlıklı ailelere kiraladıkları ve bu çocuklara "besleme", "ahretlik", "manevi evlat" gibi isimler verildiği bilinmektedir. ${ }^{68}$ Konuşma dilinde hizmetçilik ve beslemelik, ahretlik birbiri yerine kullanılan ifadeler hâline gelmiş ve aralarındaki farklar zaman zaman muğlaklaşmıştır. Evin sahibi ile görülen davalarda hizmetçiler "ücret ile hizmet eder makulesinden" şeklinde tanımlanırken ${ }^{69}$ beslemeler hakkında "hiçbir

${ }^{61}$ Milan V. Petrov, “Everyday Forms of Compliance: Subaltern Commentaries on Ottoman Reform, 1864-1868”, Comparative Study of Society and History, 2004, s. 734.

62 Başbakanlık Osmanlı Arşivi (BOA), Meclis-i Valâ (MVL) Dosya: 950, Gömlek: 25, 13 Muharrem 1279 (11 Temmuz 1862).

${ }^{63}$ S: Orada hizmetkâr mıydın? C: Evet efendim hizmetkâr idim. Beni zor ile köyden alıp hizmetkâr ettiler sonra bu işi de yaptılar.

${ }^{64}$ Yavuz Selim Karakışla, Osmanlı Hanımları ve Hizmetçi Kadınlar (1869-1927), Akıl Fikir Yay., İstanbul 2014, s. 12-15. II. Meşrutiyet döneminde açılan hizmetçi idarehaneleri hakkında bkz. Kışla, age., s. 51-52.

${ }^{65}$ Ferhunde Özbay, "Evlerde El Kızları: Cariyeler, Evlatlıklar, Gelinler", Feminist Tarih Yazımında Sinıf ve Cinsiyet, Ed. Leonore Davidoff, İletișim Yay., İstanbul 2016, s. 22.

${ }^{66}$ Lucy M. J. Garnett, The Women of Turkey and Their Folklore, London: David Nutt, 1890, s. 307-308.

${ }^{67}$ Nazan Maksudyan, "Foster-Daughter or Servant, Charity or Abuse: Beslemes in the Late Ottoman Empire", Journal of Historical Sociology, 21/4, Aral1k 2008, s. 490-491.

${ }^{68}$ Abdurrahman Kurt, Bursa Sicillerine Göre Osmanlı Ailesi (1839-1876) Sosyo-Ekonomik Yapı Gelenek ve Görenekler, Sentez Yay., Ankara 2013, s. 102-103.

${ }^{69}$ Yahya Araz, 16. Yüzyıldan 19. Yüzyıl Başlarına Osmanlı Toplumunda Çocuk Olmak, Kitap Yay., İstanbul 2013, s. 159. 
ücret vermeyerek ancak bir boğaz tokluğuna" ifadelerine yer verilmesi ${ }^{70}$ her iki statü arasında ücretli çalışmaya dayalı bir fark olduğunu gözler önüne sermektedir. Bu fark ileriki yıllarda Meclis-i Mebusanda temettü vergisi hakkındaki görüşmeler sırasında evlerde hizmetçi gibi aylık maaşla değil de "ahretlik" adı altında çalışanların bu vergiden muaf tutulacağı ifade edilirken de gösterilmiştir. $^{71}$

Petkane hakkında sorgulama yapılırken zanlı Riza da onun kendi evlerinde bir süre hizmetkârlık yaptığını, ayrılma vakti geldiğinde hakkını alıp köyüne gittiğini ifade eder. Kendisi, her ne kadar köyünden zorla alındığını ifade etse de sorgu hâkimi bu nokta üzerinde durmamıştır. Petkane'nin bu evde besleme ya da ahretlik statüsünde değil hizmetçi olarak iş yaptığını söylemek yanlış olmayacaktır. Petkane hizmetli olduğu evden ayrılırken geçen zaman boyunca çalıştığının karşılığını alarak ayrılmış görünmektedir.

Hizmetçi ya da besleme adıyla bir ailenin yanında barınan kızların aralarında sınırları tam olarak çizilemese de birtakım farklar olduğu ortadayken bazı talihsizlikler ise onların ortak noktası hâline gelebiliyordu. Yapılan çalı̧̧malarda besleme kızların iki sebeple mahkemelere gittiği ortaya konulmuştur. Bu sebeplerden biri besleme olarak kaldıkları süre boyunca yaptıkları hizmetin karşılığını almak, diğeri cinsel saldırı davası açmaktı. ${ }^{72}$ Şüphesiz bütün besleme ve hizmetçi kızların hepsi için bir genelleme yapmaksızın yine de söylemek gerekir ki bu kızların cinsel olarak savunmasız oldukları bir gerçekti. ${ }^{73}$ Hizmetçi kızların bu durumu aynı yüzyılda farklı kültürler için de geçerliydi. Paris’te 19. yüzyılın ikinci yarısında fuhuş konusunda yapılan bir çalışmada fahişe kadınların büyük kısmının hizmetçiyken evden hamilelik sebebiyle sokağa atılan kadınlar olduğu iddia edilmiştir. Bu araştırmada kızların sadece yoksulluk sebebiyle değil aynı zamanda memleketlerinden uzak ve kapısı kilitli olmayan odalarda yaşadıkları için baştan çıkarılmaya hazır oldukları yönünde oldukça önyargılı bir ifade kullanılmıştır. ${ }^{74}$ Yine İngiltere'de yapılan başka bir çalışma hizmetçi kızların her zaman kötü muameleye maruz kalmasa da savunmasız hâllerinin cinsel istismara açık kapı bıraktığını ortaya koymuştur. ${ }^{75}$ 18. yüzyıldan bir Fransız ceza hukukçusu kanunları yorumlarken iyi ahlaklı bir kıza tecavüzün idamla cezalandırılması gerektiğini ifade edip "hizmetçisini iğfal eden efendinin" bekâret karşılığı başlık parasını vererek cezasını çekmiş olacağını iddia etmiştir. ${ }^{76}$

Osmanlı hanelerinin "incinebilir" bir unsuru da cariyelerdi. ${ }^{77}$ İslam hukukuna göre sahibinden çocuk doğuran cariye, hayattayken onu azat etmese de efendisinin ölümü ile özgür kalabilirdi. Ancak bu durumun öncelikli şartı efendinin çocuğun kendisinden olduğunu kabul etmesiydi. Sahibi kabul etse de cariye miras hakları için mahkemeye gittiğinde ailenin diğer fertlerinin güçlü karşı çıkışlarına maruz kalabiliyordu. ${ }^{78}$ Yahya Araz çalışmasında ümm-i veled iddiasıyla mahkemelere gelmiş cariyeleri konu edinmektedir. Cariyeler, sahiplerinin yakın akrabaları, evin erkek hizmetçileri ve cariye sahiplerinin iş yerlerindeki arkadaşları, ortakları ve çalışanları, alım satım sırasında bekletildikleri evlerdeki erkek esirciler, buraya gelen yabancılar

\footnotetext{
${ }^{70}$ Maksudyan, agm., s. 494.

${ }^{71}$ Meclis-i Mebusan Zabit Ceridesi, Devre: 1, C. II, TBMM Basımevi, Ankara 1982, s.125.

${ }^{72}$ Maksudyan, agm., s. 503.

${ }^{73}$ Araz, age., s. 171.

${ }^{74}$ Rachel G. Fuchs, Leslie Page Moch, "Pregnant Single and Far From Home: Migrant Women in NineteenthCentury Paris”, The American Historical Reiew, 95/4, 1996. 1019-1020.

${ }^{75}$ Bridget Hill, Women Work and Sexual Politics in Eighteenth Century England, Taylor \&Francis e-Library, 2005, s. 80.

${ }^{76}$ Julis R. Ruff, Erken Modern Avrupa'da Şiddet (1500-1800), Çev. Didem Türkoğlu, Boğaziçi Üniversitesi Yay., İstanbul 2011, s. 173-174.

${ }^{77}$ Ehud R. Toledano, Suskun ve Yokmuşcasına İslam Ortadoğu'sunda Kölelik Bağları, Çev. Hakan Erdem, İstanbul Bilgi Üniversitesi Yay., İstanbul 2010, s. 76-77.

${ }^{78}$ Madeline C. Zilfi, Osmanlı İmparatorluğunda Kölelik ve Kadınlar (1700-1840), Çev. Ebru Kılıç, İş Bankası Yay., 2018, s. 193
} 
ve misafirler tarafından cinsel baskı ve saldırılara maruz kalabiliyorlardı. ${ }^{79}$ Gebeliği inkâr edilemez aşamaya gelmiş olan cariyelerin iddiayı ispat etme olasılığının diğer cinsel suç davalarında olduğu gibi düşük olmasına rağmen Araz'a göre yine de mahkemeye gitmelerini makul gösterecek bir sebep vardır. Cariye iddiası kabul olduğu takdirde ümm-i veled olarak özgür bir kadın olabilecektir. İstanbul mahkemelerine yansımış hemen her davanın sonucu cariye aleyhindedir. Cariye sahipleri aile içi baskılar, sorumluluktan kaçma ve cariyenin başkasından hamile kalma şüphesi nedenleriyle çocuğun babası olma iddiasını reddetmişlerdir. İddiasını ispat edemeyen bir cariyenin karşılaşabileceği en kötü olasılığın bir başkasına satılmak olduğunu söyleyen Araz, benzer durumu yaşayan hizmetçilerin mahkemeye gitmelerinin kendilerine bir şey kazandırmayacağını, bu durumun onların kovulup sokaklara düşmesine sebep vereceğini, aynı zamanda onurlarını kaybetme tehlikesiyle karşı karşıya kalacaklarını ifade etmektedir. Bu sebeplerle ümm-i veled olma iddiasıyla mahkemeye gelen çok sayıda cariye olmasına karşın evlilik dışı ilişki sonrası hamile kalmış çok az sayıda hizmetçinin mahkemelere başvurduğu sonucuna varılmaktadır. ${ }^{80}$

\section{“Irzımı Isterim”: Söylenenin Tam Anlamı Ancak Söylenmeyen Üzerine Düşünüldüğünde} Ortaya Çıkar

Onur kavramı diğer pek çok kültürel mefkûre gibi ne tek başına kişisel ne de toplumsal etkenlere bağlı olarak tanımlanabilir. ${ }^{81}$ TDK sözlüğünde de kelimenin iki yönlü anlamına işaret edilen tanımlama vardır. İlk açıklamada insanın kendine karşı duyduğu saygı, şeref, öz saygı, haysiyet, izzetinefis şeklinde, ikincisinde başkalarının gösterdiği saygının dayandığı kişisel değer, şeref, itibar olarak açıklanmıştır. Onur büyük ölçüde bir toplumsal baskı konusudur. Kendi onurunu korumayı başaramayan bir kişi toplum içindeki saygınlığını kaybeder. Öte yandan toplumsal baskı ortadan kalksa da daha önceden içselleştirilmiş değerler kişinin davranışlarını denetlemeye devam eder. Bu kültürel bir koşullanma olsa da onur dışarıdan gelen etkenler kadar kişinin içinden gelen değerlerden de beslenir. ${ }^{82}$ Onur, kişinin kendine biçtiği değer olmakla birlikte belki bundan daha önemli olarak toplum nazarında kişinin değerini gösterir. ${ }^{83}$

Tanzimat öncesi dönemde kadınların cinsel saldırıya uğradıkları iddiası ile mahkemelere gitmelerinin nedeni olarak bunun bir onur kurtarma çabası olduğu araştırmacıların değerlendirmeleri ile ortaya konmuştur. Mahkeme kayıtlarında onur kelimesine rastlanılmaz. ${ }^{84}$ Oysa Petkane'nin gerek Pazarcık meclisinde gerekse Filibe mahkemesinde sorgu hâkimleri tarafından ne istediği sorulduğunda cevabı "davam ırz davasıdır, ırzımı isterim" olmuştur:

S: Adın ve davan nedir nerelisin?

C:Adım Petkana ve Pazarcık kazasına tâbi Çerova karyeliyim ve davam ırz davamdır.

S:Kız adın nedir?

C:Ben şimdi kız değilim. Gebeyim. Adım Petkane babam Marko.

S: Ne istiyorsun?

C: Irzımı istiyorum.

Honor (İng.) ve honneur (Frs.) teriminin Farsça ve Arapçada olduğu gibi Türkçede de farklı versiyonları vardır. "Onur" ve "şeref" daha kapsayıcı anlamda kullanılırken "iffet",

\footnotetext{
${ }^{79}$ Çerkes bir köle olan Şems-i Gül'ün esirci Mehmet tarafindan istismarını ele alan çalışma için bkz. Ehud R. Toledano, "Shemsigul: A Circassian Slave in Mid-Nineteenth Century Cairo", Struggle and Survival in the Modern Middle East, ed. Edmund Burke, I.B. Tauris \&Co. Ltd. Londra1993, ss. 59-74.

${ }^{80}$ Yahya Araz, "Cariyeler, Efendiler ve Pusuda Bekleyenler: Osmanlı İstanbul'unda Hamile ve Çocuk Annesi Cariyeler Üzerine Düşünceler (1790-1880)”, Kebikeç, 37, 2014, s. 233-260.

${ }^{81}$ Lila Abu-Lughad, "Honor and Sentiments of Loss in a Bedouin Societiy", American Ethnologist, 12/2, May1s, 1985, s. 247.

${ }^{82}$ Roger A. Deal, Namus Cinayetleri Sarhoş Kavgaları II. Abdülhamid Döneminde Şiddet, Çev. Zeynep Rona, Kitap Yay., İstanbul 2017, s. 116.

${ }^{83}$ Ruff, age., s. 94.

${ }^{84}$ Pierce, age., s. 237.
} 
"namus", "izzet" ve "irz" daha cinsiyet merkezli ve en çok da kadınlarla ilgili durumlarda kullanılmaktadır. ${ }^{85}$ Sözlükte kişinin bedeni, ruhu, övgüye değer yaratılışı, soyu sopu gibi anlamlara geldiği belirtilen "1rz" kelimesinin asıl anlam itibarıyla bunlardan hangisini kapsadığ konusunda dilbilimciler arasında tartışma görülse de terim olarak 1rz, insanı insan yapan, ona toplumda şeref ve saygınlık kazandıran ve her türlü tecavüz karşısında dokunulmazlığ 1 bulunan kişilik değerini ifade etmektedir. ${ }^{86}$ Kamus-i Hukuk'ta fi'l-i şenî tanımlanırken "irz hakkında vuku bulan tasalluta itlak olunur. Binaenaleyh mutlaka cim'â etmek manasında değildir " denilmiş, ancak zamanla terimin kişilik değerlerinden sadece iffet ve cinsellikle ilgili olan kısmı anlaş11ır olmuştur. ${ }^{88}$

"Söylenenin tam anlamı ancak söylenmeyen üzerine düşünüldüğünde açığa çıkabilir". ${ }^{89}$ 1839 Tanzimat Fermanı'nda tebaanın can, mal, ırz ve namusunun padişahın koruması altında olduğu ifade edilmektedir. Abdurrahman Şeref, burada 1rzın korunmasının belirtilmesini anlamsız bulduğunu söylemektedir. Çünkü "irza saldırmak geleneklerimize ve millî terbiyemize aykırıdır. 'Irz padişahındır' sözü, korunmasının padişaha emanet edilmiş bir millî hak, bir manevi hazine olduğu ve kimsenin ona dokunamayacağ anlamına gelmektedir. Bu durum millî geleneklerimizle doğrulanmıştır". ${ }^{90}$ Tanzimat'ın ilanını takip eden 1840 tarihli Ceza Kanunu'nda "ırz ve namus kişinin can gibi aziz ve muhterem olarak korunmal, bir adamın itibarına dokunacak söz söylemek, bir adamı dövmek ve bir şahsa sövmek onun namusunu hetk etmek olarak görülmüştür." denilmiştir. 1851 Kanunu'nda da buna yakın ifadelerle aynı madde korunmuştur. ${ }^{91}$ Esasen bütün tebaanın ırzının padişah tarafından koruma altında olması Osmanlı yönetim ilkesinin temelini oluşturan daire-yi adliyye anlayışının bir parçasıdır. 18. yüzyıl ahkâm defterlerinde oldukça sık geçen "hetk-i ırz" şikâyetleri tebaanın padişahtan beklentisini ortaya koymaktadır. Onur ve namusu korunan bir halk başındaki padişahın varlığını meşru görecektir. Namusu sürekli tehlike altında olan halk ise üzerindeki gücü işe yaramaz bulup meşruiyetini tartışır hâle gelecektir. ${ }^{92}$

Petkane, "ırzımı isterim" derken, bunun padişahın ve yasaların koruması altında olduğunun bilincinde olmalıdır. Petkane ve Rıza'nın şer'î mahkemede davaları görülmüş, ancak Rıza suçu inkâr edip, Petkane'nin iftira ettiğini söylemiş, sonuç olarak Rıza'ya şer'an bir ceza verilmemiştir. Petkane şer’̂̂ mahkemeden sonuç alamayınca davasının liva meclisine gönderilmesinde 1 srar etmiştir. ${ }^{93}$

Pazarcık ve Filibe meclislerinde yapılan sorgulamalarda hâkimler Petkane'ye Rıza'nın kendisine zor kullanıp kullanmadığını, olayın yaşandığı anda bekâret durumunu sormuşlardır. Petkane cevaplarında olayın zorla gerçekleştiğini ve o esnada bakire olduğunu ifade etmiştir:

S: Riza sana kuvvet ilişdi mi ve zor ile mi oldu ve nerede oldu söyle.

C: Geçen Kasım'dan iki gün sonra Rıza'nın hanesinde beni bozdu ondan gebe kaldım sonra ayağımdan kan aldırdı ve muallece yaptırdı çocuğu düşürmek için.

S: Sen kız mı idin yoğsa karı mı?

C: Kız idim ve bu Rıza'nın evinde hizmetkâr idim. Bundan altı ay mukaddem Kasım mevsimi evde kimse olmadığı hâlde bu Rıza gelip cebren ırzıma geçti ve şimdi hamileyim

85 Başak Tuğ, “Gendered Subjects in Ottoman Costitutional Agreements, c.a. 1740-1860”, European Journal of Turkish Studies, 18, 2014, s. 19.

${ }^{86}$ Hayati Hökelek, “’”Irz”, DIA , C.19, 1999, s. 133.

${ }^{87}$ Hüseyin Galip, Kamus-i Hukuk, Cemal Efendi Matbaas1, İstanbul1305, s. 174.

${ }^{88}$ Hökelek, agm., s. 134.

${ }^{89}$ Irvin Cemil Schick, Bedeni, Toplumu, Kâinatı Yazmak İslam, Cinsiyet ve Kültür Üzerine, Çev. Pelin Tünaydın, İletişim Yay., İstanbul 2014, s. 22.

90 Abdurrahman Şeref, Tarih Musahabeleri, Sadeleştiren: Enver Karay, Kültür ve Turizm Bakanlığı Yay., Ankara 1985, s. 42.

${ }^{91}$ Ahmet Lütfi, Mir'at-ı Adalet yahut Tarihçe-i Adliye-i Devlet-i Aliyye, Matbaa-i Nişan Berberyan, İstanbul 1304, s. $128,132,136$.

92 Tuğ, agm., s. 6-7.

93 "Dava ederim. Burada olmazsa Filibe'ye giderim elbet ırzımı Rıza'dan isterim". 
Burada Petkane'nin olayın zorla gerçekleştiğine ve o esnada bakire olduğuna mahkemeyi ikna ettiğini varsayarak dönemin ceza uygulaması üzerine bir değerlendirme yapabiliriz. 1858 Ceza Kanunu'nun 198. maddesinde "Bir adam bir kimseye cebren fi'l-i şenî icra eder ise yani ırzına geçerse muvakkaten küreğe konur." ${ }^{94}$ denilmiştir. Cebir ise şöyle açıklanmıştır: "...ırzına kastettiği kimsenin mukavemetine ve mümanaatına bakmayarak üzerine yüklenip veya kolların bağlayıp veya kendisini mukavemetten men edecek başka bir fiil-i müessir icra eyleyip mesela bayltacak bir ilaç içirip veya sarhoş edip vesair bunun emsali şeyler yapıp fiil icra etmektir". İğfâl ise "Akçe ve sair şey ita veya vaad ile ıtmâ veya tezevvüç edeceğim gibi bir hâl ile ika eylemek ve sair şunun gibi şeyler yapmaktır." şeklinde açıklanmıştır. ${ }^{95}$

Kanun'un 200. maddesinde "Ĕger cebren fi'l-i şenî henüz hiç evlenmemiş klza yapılırsa bunu yapan kimse kürek cezasından başka tazminat ödemeğe müstahaktır." denilmiştir. ${ }^{96}$ Ancak bu hükmün ortaya çıkması için ya erkek izdivaç vaadiyle karşı tarafı iğfal ettiğini ikrar ve itiraf etmeliydi ya da kız tarafının iddiasını ispat etmesi gerekmekteydi. ${ }^{97}$

Meclis-i Vâlâ kararları incelendiğinde pek çok tecavüz suçunun 3 ile 5 yıl arasında kürek cezasıyla cezalandırıldığı, kurbanın bakire olması durumunda cezaya ek olarak tazminat ödenmesine karar verildiği görülmüştür. Irza tecavüz adam öldürme ya da eşkıyalık gibi bir suçla birleştiği takdirde ceza 15 yıl kürek ve bazen de idam olarak karara bağlanmıştır. ${ }^{98}$ Petkane iddiasını ispat ettiği takdirde Rıza'nın işlediği suç bikr-i baliğaya cebren fi'l-i şenî kabul edilecek, en az 3 yıl küreğe konulup, Petkane'ye tazminat ödemiş olacaktı. Böylece Petkane onur davasını kazanmakla beraber babasının kim olduğu bilinmeyen bir çocuğu dünyaya getirme yükünden kurtulmuş olacaktı. Babasız bir çocuk doğurmayı istememesi Petkane'nin vermiş olduğu 1 rz davasının bir nedenidir. Bu şekilde Tikveş’te dört kişinin tecavüzüne uğradığını iddia edip ancak bunu ispat edemeyen bir Bulgar kadını çocuğunu dünyaya getirince köy papazı çocuğu vaftiz etmemiş dahası köy ahalisi kadını çocuğuyla beraber merkez kazaya gönderip orada hükûmetin bakımına bırakmasını istemişlerdir. ${ }^{99}$ Dimetoka'ya bağlı Kuru köyünden Kıpti Fatma "veled-i zina"sı olan bir buçuk yaşındaki Abdi'yi derede üzerine taş koyarak boğmuştur. Fatma ve Abdi'nin üvey babası zenci Mercan savunmalarında bu gayrimeşru çocuk yüzünden gittikleri yerlerde kabul görmediklerini, en son Demirci köyünden de çocuğun "piç" olması sebebiyle kovulduklarını söylemişlerdir. ${ }^{100}$

Petkane'nin mahkemeyi inandırdığı takdirde bir diğer ve bu sefer daha somut kazanc1 salim bir evlilikte kadının alacağı tazminat olan mehiri elde etmek olacaktı. Sonrasında da bir dul olarak kazandığı kültürel cinsiyet kimliğiyle bundan sonra olası evlilik tekliflerine açık olabilecektir. ${ }^{101}$ Orta Doğu ve Akdeniz kültüründe benimsenen ahlak anlayışı iffetine el sürülmüş bir kadının evlenmesini ve ergin kişi kimliği edinmesini zorlaştırmıştır. ${ }^{102}$ Kütahya sancağında bir çiftlikte yaşayan Ümmühan, aynı çiftlikte yaşayan Mehmet'in, bikrini izale ettiği iddiasıyla mahkemeye gitmiş, şer'î mahkemede görülen davada Mehmet suçunu inkâr etmiş ve Ümmühan da iddiasını ispat edemeyince Mehmet güçlü bir kefile bağlanarak salıverilmiştir. Mahkemenin ertesi günü "Bundan sonra beni kimse kabul etmez." diyen Ümmühan kendini zehirleyip intihar etmiştir. Bu olayın akabinde Meclis-i Vâlâ davanın sadece şer'an görülmesine

\footnotetext{
${ }^{94}$ Düstur, I. Tertip, C. I, Matbaa-i Âmire, İstanbul 1289, s. 579.

${ }^{95}$ Halil Rifat, Külliyat-l Şerh-i Ceza, Mihran Matbaası, İstanbul 1312, s. 313.

${ }^{96}$ Düstur, I/I, s. 579.

${ }^{97}$ Halil Rifat, age., s. 317.

${ }^{98}$ Konan, agm., s. 164-166.

${ }^{99}$ BOA, Bab-ı Âli Evrak Odası (BEO), 931/69777.

100 BOA, Irade Divan-ı Ahkâm-ı Adliye, 12/449, 10 Şaban 1290 (3 Ekim 1873). Fatma idam cezasına mahkûm edilmişse de sonradan bu 15 sene hapse çevrilmiş, Mercan'a da 3 yıl hapis cezası verilmiştir.

${ }^{101}$ Toplumsal cinsiyet kimlikleri hakkında bkz. Leslie Pierce, "Ekberiyet, Cinsellik ve Toplum Düzeni: Modern Dönemin Başlangıcında Toplumsal Cinsiyetle İlgili Osmanlı Söz Dağarcı̆̆ı”, Modernleşmenin Eşiğinde Osmanlı Kadınları, Ed. Madeline C. Zilfi, Çev. Necmiye Alpay, Tarih Vakfi Yurt Yay., İstanbul 2000, s. 166-193.

${ }^{102}$ Pierce, age., s. 476.
} 
itiraz edip Mehmet'in Ümmü’nün ölümüne sebebiyet vermekten nizamiye mahkemesince tekrar sorgulanmasına karar vermiştir. ${ }^{103}$

Gerçekte Petkane'nin iddiasını ispat etmesi kolay olmamıştır. Kadının hamileliğin üzerinden altı ay geçtikten sonra mahkemeye gelmesi onun iddialarını zayıflatan, inandırıcılığını sorgulatan unsurlardan biriydi. Bu geç gidiş mahkemece başlangıçta Rıza'nın evlilik vaadinde bulunarak olayın her iki tarafin isteğiyle gerçekleştiği, ancak sonrasında Rıza'nın vazgeçmesiyle Petkane'nin böyle bir iddiayı ortaya attığı şeklinde yorumlanmış görünmektedir:

S: Ya bu iş geçen Kasım'dan iki gün sonra olmuş diyorsun ol vakitten beri hiç dışarıya çıkmadın mı ve ananı ve babanı görmedin mi? Niçün onlara söylemedin? Hele bu iş zor ile olmadığı gibi anlaşılır doğrusunu söyle.

C: Efendim korkutuyorlar idi onun için söylemedim.

$\mathrm{S}$ : Ne ise arasını uzatmışsın.

C: Ne yapayım korkudan arası uzadı. Şimdi geldim dava ederim burada olmazsa Filibe'ye giderim elbet 1rzımı Riza'dan isterim.

S: Benim işittiğime göre bu iş cebren olmayıp riza ile olmuş ve bu seni bir sene kadar Müslüman edip alacağım seni diyerek kullanmış ve sen de ona varmak istermişsin sonra o almaklıktan caymasıyla sen böyle davaya kalkışmışsın. Böyle midir?

C: Öyle değildir.

Yargı sistemi için ideal olan cinsel saldırıya maruz kaldığını iddia eden kadının olayı zaman kaybetmeden mahkemeye bildirmesiydi. Bu durumda kabile kadınlar tarafindan yapılan muayene ile hem bekâretin kısa bir süre önce kaybedildiğini tespit edilebiliyor hem de zor kullanılıp kullanılmadığı anlaşılabiliyordu. ${ }^{104}$ Nitekim sakk mecmualarında ${ }^{105}$ yer alan kadı hükümlerinde davacının iddiasının kabul olunması için olayın üzerinden 1 aydan fazla zaman geçmemiş olması gerektiğine, aksi durumlarda iddianın esastan reddedileceğine dair örnekler bulunmaktadır. ${ }^{106}$

Petkane'nin iddiasını ispat edebilmesinin bir yolu mahkemeye tanıklar getirebilmesiydi. Rıza'nın çocuğu düşürtmek için işbirliği yaptığı bir Yahudi hekim, iki Çingene kadın ve bir diğer hekim Hristo'yu mahkemeye tanık olarak göstermiş, bunlardan ilk üçü iddiayı inkâr etmişlerdir. Hekim Hristo ise yapılan sorgulamasında Rıza'nın Petkane'nin karnındaki çocuğu düşürmesi için kendinden yardım istediğini, evine giderek yalandan bir ilaç veriyormuş gibi yapıp inandırıcı olmak için kızın ayağından kan aldığını, kendisine 20 kuruş ödeme yaptığını itiraf etmiştir. Burada 1858 Ceza Kanunu ile çocuk düşürmeye sebep olmaya ağır yaptırımlar getirildiğinin hatırlanması gerekir. 193. maddede hamile bir kadına rızası dâhilinde olsa bile düşük yapması için ilaç içiren ya da başka yollarla yardımcı olan kişinin altı aydan iki seneye kadar hapsolunacağı ve eğer buna sebep olan kişi tabip, cerrah veya eczacı ise muvakkaten küreğe konulacağı ifade edilmektedir. ${ }^{107} \mathrm{Bu}$ cezalar Yahudi hekim ve Çingene kadınların olayı inkâr etmelerinde etkili olmuş olabilir.

Petkane’nin lehinde görünen bir diğer durum ise Rıza'nın benzer suçtan töhmetli olmasıdır. Daha önceden yine evinde hizmetçilik yapan Saatçi Ahmet'in kızı da aynı iddiada bulunmuş, Rıza suçlamayı kabul etmemiş, şer'î dava dahi görülemeden kızın iddiası sürüncemede kalmış ve çocuğunu bu şartlarda doğurmak zorunda kalmıştır. Pazarcık meclis mazbatasında da belirtildiği üzere Petkane de doğumdan önce çocuğun babasını bulamaz ise

\footnotetext{
${ }_{103}$ BOA, Sadaret Umum Vilayet Evrakl (A. MKT. UM), 392/77, 4 Receb 1276 (27 Ocak 1860).

${ }^{104}$ Sonbol, agm., s. 218.

105 Sakk mecmuaları hakkında bkz. Süleyman Kaya, "Mahkeme Kayıtlarının Kılavuzu: Sakk Mecmuaları”, Türkiye Araştırmaları Literatür Dergisi, C. 3, S. 5, 2005, ss. 379-416.

${ }^{106}$ Debbağzade Numan Efendi, Tuhfetu's-Sukuk, Darü’t-Tibaati'l-Âliye, İstanbul 1259, s. 292.

${ }^{107}$ Gülhan Erkaya Balsoy, Kahraman Doktor İhtiyar Acuzeye Karşı Geç Osmanlı Doğum Politikaları, Can Yay., İstanbul 2015, s. 130.
} 
kucağında çocuğuyla ortada kalmanın korkusunu yaşamaktadır. Hâkim, Rıza'yı töhmet altında bırakan bu olayı hatırlatarak sorularını tekrarlasa da Rıza iddiaları yine reddetmiştir:

S:Ya bundan bir sene mukaddem Saatçi Ahmet'in kızı sende hizmetkâr iken onun karnına dahi bir çocuk yaptın elân merkum çocuk anasının kucağında ol vakit senden dava ettiler idi. Yine inkâr ile kurtuldun. Böyle aygır gibi hâl hareketinin mücâzatını göreceksin.

C: Hayır efendim, ben böyle şey bilmem yapmamışım ve kabul etmem.

Nihai olarak Meclis-i Vâlâ, Hekim Hristo'nun tanıklığını tek başına şer'an ya da kanunen bir hüküm vermeye yeterli görmemiştir. Ancak Petkane'nin mahkemeye yeni deliller getirmesi hakkını saklı tutarak, Rıza'nın sabıkası nedeniyle olayın bir kere daha tetkik ve tahkik edilmesi gerektiğini belirtmişse de mevcut durumda Rıza'ya bir ceza verilmeyip salınmasına hükmetmiştir.

\section{Cinsel Saldırı Davaları: Geleneğin Devamı ve Farklar}

Tanzimat'ın ilanını takip eden dönemde Osmanlı yöneticileri merkezî gücü artırma konusunda bir dizi önlem alıp yenilik getirmek istemiştir. Bu kapsama giren sosyal, siyasi ve ekonomik konulardan biri ceza hukuku ve daha dar anlamda da cinsel suçların cezalandırılması olmuştur. Esasen Osmanlı Devleti'nin ahlak ve cinsellikle ilgili konularda düzenlemeleri yakın takibe alması ve bu konularda cezaların uygulanmasını merkezî yönetime devretme çabaları 18. yüzyıldan itibaren kendini göstermiştir. Bu yüzyılda Ankara ve Bursa kadıları değnek ile mahalleden ihraç gibi daha basit cezalar gerektiren suçlar dışındaki ağır cinsel suçların cezalandırılmasını merkeze bırakmak durumunda kalmışlardır. ${ }^{108}$

1858 Ceza Kanunu'nun 3. faslı "Hetk-i Irz Edenlerin Mücazatı” başlığını taşımaktadır. Hetk-i 1rz; hakaretten bedene dokunma, onuru lekeleme ve tecavüze kadar varan bir dizi anlam içermektedir. ${ }^{109} 18$. yüzyıl ahkâm defterlerinde ve mahkeme kayıtlarında hetk-i irz genellikle eşkıya takımının zalimliği ve başkalarının onuruna saldırmaları hakkındaki şikâyetlerde geçmektedir. Birinin evine zorla girmek, başkalarının karılarına ve kızlarına saldırmak, onları karalamak ve bazı durumlarda da fiziksel saldırı suçları için kullanılmıştır. ${ }^{110} 1858$ Kanunnamesi'nde bu başlık altında çocukların cinsel istismarı, cebren fi'l-i şenî, izale-i bikr, zina, elle sarkıntılık, kişileri fuhşa sevk etmek gibi cinsellikle ilgili suçlar sayılmıştır. Hetk-i ırz teriminin bu şekilde kullanılması cinsel suçlarda onur üzerine yapılan vurgunun arttığını, cinsel suçların daha görünür hâle getirildiğini düşündürmektedir. ${ }^{111}$

Yeni ceza kanunları ve hukuksal düzenlemelere yer verilen bu dönemde cinsel saldırı mağduru olan kadınların lehine bazı değişmeler olduğu söylenebilir. Ele alınan vakada da görüldüğü gibi bu dönem yargısal düzenlemeleri şer'î mahkemede çözümlenemeyen bir davayı davacının nizamiye mahkemesine taşımasına ve burada daha derinleştirilmiş bir tahkikat sürecinden geçirilmesini talep etmesine imkân sağlamıştır. İslam hukuku cinsel suçları cezalandırmada kesin delil prensiplerini benimsediği için davacının bu delilleri mahkemeye sunamaması durumunda mahkeme iddianın reddine hükmedebiliyordu. Hâkimin takdir yetkisi kullanamadığı bu tür ceza davalarında davacı tanık gösteremeyip davalı da suçlamayı inkâr edip iyi hâline şahitler getirip yemin verdiği takdirde bir ceza almıyordu. Ancak burada özellikle iyi hâli ispatın zor ilkelere bağlandığının altını çizmek gerekir. Şer'î mahkemeler gebeliğin üzerinden zaman geçtikten sonra açılan davaları esastan reddedebiliyordu. 1869'da Çorum'da tecavüze uğradığ 1 iddiasıyla kadı mahkemesine giden kadınının davası "zinâ hususunda bir aydan ziyâde tekâdüm-i zamân" gerekçesiyle reddedilmiştir. ${ }^{112}$ Nizamiye mahkemeleri diğer

${ }^{108}$ Tuğ, agt., s. 375-376.

${ }^{109}$ Sonbol, agm., s. 212.

${ }^{110}$ Tuğ, agt., s. 200.

111 Tuğ, agt., s. 201-202.

112 Zekeriya Işı1k, “Osmanlı İmparatorluğu'nda Kamusal Alanda Cinsiyet ve Toplumsal Cinsiyet Kimliğiyle Kadın

(1839-1900): Çorum Şer’iyye Mahkemesi Örneği”, Bilig Türk Dünyası Sosyal Bilimler Dergisi, S. 85, s. 31-32. 
ceza davalarında olduğu gibi kesin deliller dışında delillerin de incelenmesine şans verebilmektedir.

Tanzimat sonrası ceza kanunu usulünde belki de en belirgin değişiklik hâkimin takdir yetkisinin içerik olarak değişmesidir. Bu dönem öncesinde İslam hukuku kuralları çerçevesinde ceza davalarında hâkimlere sadece kesin delillere göre karar verme yetkisi tanınıyordu. Kesin delil olarak ise ikrar, şahitler, nükûl ve bazen de bilirkişi beyanı haricinde delil kabul edilmiyordu. İslam ceza hukukuna göre hâkimin delil arama yükümlülüğü yoktur. Bu delilleri toplayıp mahkemeye sunmak davacının sorumluluğundadır. Tanzimat sonrası dönemde ise vicdani delil benimsenmiş, hâkimler sadece kesin delillere bağlı kalarak değil takdirî delilleri de değerlendirerek karar almaya başlamışlardır. ${ }^{113}$

Öte yandan bu dönem davaların soruşturma aşamasında davacı ve davalının töhmetli olup olmadığ 1 ve yaşadığ çevrede nasıl bilinen kişiler olduğu ilkeleri önemini korumaya devam etmiştir. Evlilik vaadiyle aldatılıp izâle-i bekâret davasıyla Memlik mahkemesine başvuran Hristiyan bir kadının iyi hâli çevresindeki saygın Hristiyanlara sorulmuş "fena bir yola insilâk" etmiş bir kadın olduğu, bu sebeple polis kayıtlarında adı olduğu ve zaten daha önceden başka bir evlilik yaşadığı ortaya çıkarılmıştır. ${ }^{114} \mathrm{Bu}$ dönem özellikle meşru müdafaa davalarında hem davalı hem davacının nasıl kişiler olduğu dava sonucunu belirleyen önemli bir unsur olmuştur. 1865 yılında Priştine sancağı, Vulçitrin kazası Okraşince köyünde ırzını müdafaa için adam öldüren kadın "saliha hatun" ve "ehl-i trz makulesinden", maktul de "uygunsuz güruhundan" ve "haylaz ve çapkın makulesinden" olduğu için kadına ceza verilmemiştir. ${ }^{115} 1864$ 'te Rusçuk'ta yaşanan olayda evin camını kırarak içeri girmek isteyen adamı ateş açarak öldüren kadınlar "ehl-i iffet olmadiklarından" bu bir muhafaza-i irz olarak kabul edilmemiş, 15 ve 7'şer sene hapisle cezalandırılmışlardır. ${ }^{116}$ Petkane'nin davasında ise mahkeme Rıza'nın sabıkalı olmasına işaret etmiş, kadının iyi hâlinin soruşturulmasına ihtiyaç duymamış görünmektedir.

1858 Ceza Kanunu'nu takip eden yıllarda özellikle 1908 sonrasında yapılan hukuksal düzenlemelerle cinsel saldırı suçları şahsa karşı işlenen bir suç olmaktan çıkarılıp giderek artan ölçülerde kamuya karşı işlenen bir suç olarak görülmeye başlanmıştır. Kadın bedeni üzerinden toplumsal düzenin sağlanması bazen yasanın hilafina karar verilmesine sebep olabilmiştir. 1907'de İstanbul'da yaşanan olayda evli olan bir kadına cebren fi'l-i şenî eden şahıslar başlangıçta suçu inkâr etseler de uzun tahkikat süreci nihayetinde içlerinden biri suçu ikrar etmiştir. Zanlıların suçlu olduğu apaçık ortada olduğu hâlde "ehl-i iffet ve zâtü'z-zevc bir kadın hakkında bu dereceye kadar cüretleri âlemü'l-İslamiyete karşı pek çirkin bir şey olup işin şüyu-ı muhazzirden gayr-i sâlim görünmüş olduğundan" suçluların bekâr ve İstanbul'un yabancis1 olmaları göz önünde bulundurularak Diyarbakır gibi bir mahalle sürülmelerine karar verilmiştir. ${ }^{117}$

1908-1918 arasında kız kaçırma ve fi'l-i şenî ile ilgili pek çok yasal düzenleme yapılmıştır. 1911'de yapılan düzenleme ile kurbanın kadın-erkek, 15 yaşından küçük-büyük, evli-bekâr olmasına göre ve kaçırma ile beraber tecavüzün vuku bulup bulmadığına göre cezalar

113 Feyza Tenger, İslam Hukukunda Hâkimin Takdir Yetkisi Bă̆lamında Kendi Bilgisiyle Hüküm Vermesi, Yayımlanmamış YLT, Ankara Üniversitesi, 2006, s. 32-34; Ebru Aykut, "Osmanlı Mahkemelerinde Şüpheli Zehirlenme Vakaları, Adlî Tıp Pratikleri ve Tıbbi Deliller”, Tarih ve Toplum Yeni Yaklaşımlar, 17, Bahar 2014, s. 10.

${ }^{114}$ BOA, Teftişat-ı Rumeli Evrakı Jandarma Müşiriyet ve Kumandanlık Evrakı (TFR. I.AS.) 44/4373, 7 Safer 1325 (26 Mart 1907).

${ }^{115}$ BOA, Meclis-i Valâ (MVL), 1029/81, 27 Muharrem 1283 (11 Haziran 1866); MVL, 1023/54, 6 Receb 1283 (14 Kasim 1866).

${ }^{116}$ BOA, MVL, 990/20, 23 Muharrem 1281 (28 Haziran 1864).

117 BOA, BEO 31008/233051, 13 Cemaziyelahir 1325 (24 Temmuz 1907). Bu hükmün öncesinde olayla ilgili gelişmelere ait mahkeme tutanakları Roger Deal tarafından verilmiştir (Namus Cinayetleri, s. 132-134). 
tespit edilmiştir. ${ }^{118}$ Düzenlemeye göre kaçırılan kıza nikâh kıyılmasıyla 15 yaşını doldurmuş ise kendisinin doldurmamışsa velisinin davadan feragat etmesiyle kamu davasının düşeceği ifade edilmiştir. Miller, bu maddenin kendinden önceki düzenlemelerden ciddi bir farklılık gösterdiğini evlilik yolu ile sapkın bir fiilin masum bir fiile çevrilmesinin yolunun açıldığını iddia eder. $^{119}$

Bu madde 1911'de Kanun metnine girerek hukuksal bir nitelik kazanmışsa da bundan önce de uygulamada olduğu bilinmektedir. 1864'te Saraybosna'da kurbanı ile nikâh kıyıp dört gün sonra da boşadığı anlaşılan adam hapse atıldığında kadın peder ve maderinin olmadığını ve idareden aciz olduğunu söyleyerek tecavüzcüsünün affedilip tekrar kendisini nikâhına almasını rica eden bir arzuhâl vermiştir. Ancak yetkililer cezadan kaçmak için böyle hile yoluyla nikâh tertip etmenin başkalarına da kötü örnek olması ve böyle yollara başvuracakları korkutmak için 200. madde gereğince adamın 6 ay hapsine ve kadına da bekâretinin tazmini için iki bin yüz kuruş ödenmesine karar vermiştir. ${ }^{120}$

Miller, İttihat Terakki döneminde çıkarılan af kanunlarının hetk-i 1rz ve fi'l-i şenî suçluları haricindekileri kapsamasını da bu dönemde bu suçların kadın bireye karşı işlenmiş suçlardan ziyade sosyal organizmaya ve devlete karşı işlenmiş suçlar gibi telakki edildiğini ifade etmektedir. ${ }^{121} \mathrm{Bu}$ türden suçların af kapsamına alınmamasının Osmanlı Devleti'nde "Irz padişahındır" anlayışıyla ilgili olduğunu düşünebiliriz. Nitekim 1902'de Abdülhamid'in doğum günü sebebiyle çıkarılan af kanununda irza tecavüzden mahkûm olanlar hariç tutulmuştur. ${ }^{122}$ Dahası bunun çok öncesinde 18. yüzyıl başlarında ırza tecavüz suçlularının genel bir aftan faydalanamayacağı belirtilmiştir. ${ }^{123}$

\section{Sonuç}

Bu çalışma, "Günümüzde tecavüz kurbanı kadınların yasal mercilere gitmek konusunda çekingen tutum gösterirken bu suça maruz kaldıklarını iddia eden Osmanlı kadınlarının mahkemeye gitmesini sağlayan saikler nelerdi? sorusundan ortaya çıkmıştır. Şer'iyye sicilleri ve ahkâm defterleri üzerine daha önceden yapılan çalışmalarla bu saiklerin neler olabileceği ortaya konmak istenmiştir. Sicil kayıtlarının ceza davaları hakkında verdiği sınırlı bilgilerden yola çıkılarak kadının tazminat elde etmek, davalı ile nikâhlanmak, şayet olay sonucu bir gebelik var ise doğacak çocuğuna nafaka sağlamak ve toplum nezdinde itibarını kurtarmak gibi beklentilerle mahkemelere gitmiş olabilecekleri yönünde değerlendirmeler yapılmıştır. ${ }^{124} \mathrm{Bu}$ çalışma, 19. yüzyılda zor ile cinsel ilişki yaşayıp hamile kaldığını iddia eden bir köylü, bir hizmetçi ve genç bir Osmanlı kadınının dava açma nedenini kendi ifadeleriyle ortaya koymaya çalışmıştır. Osmanlı yönetim anlayışının bir parçası olarak bütün tebaanın ırzının padişahın koruması altında olması ilkesi öteden beri Osmanlı kadınlarının onurlarına bir saldırı olduğu takdirde mahkemeye gitmelerinin meşru zeminini oluşturmuş görünmektedir. 19. yüzyılda yapılan düzenlemelerle ise ırzın korunması padişahın himayesiyle birlikte ceza kanunlarının da koruması altına alınmıştır. 1858 Ceza Kanunu'nda hetk-i ırz başlığı altında cinsel suçlar yetişkin-küçük, şiddet içeren-içermeyen, kamusal-özel gibi ayrımlar çerçevesinde sınıflandırılıp önceki yasalara göre daha şiddetli cezalar getirilmiştir. ${ }^{125} \mathrm{Bu}$ dönemde yapılan hukuksal

\footnotetext{
${ }^{118}$ Fatih Öztop, "Suç Cetvellerine Göre Osmanlı Devleti’nde 'Kız Kaçırmak' Suçu: Aydın Vilayeti Örneği (19081916)”, TIDSAD, S. 2, Mart 2015, s. 290.

${ }^{119}$ Ruth A. Miller, Osmanlı'dan Cumhuriyet'e Günah ve Suç Fıkıhtan Faşizme, Çev. Hamdi Çilingir, Ufuk Yay., İstanbul 2013, s. 149-150.

${ }^{120}$ BOA, Taşra Evrakı Bosna Müfettişliği Evrakı (TŞR. BNM) 28/161, 7 Rebiülahir 1281 (8 Eylül 1864).

${ }^{121}$ Miller, age., s. 150-151.

122 BOA, Ylldız Mütenevvi Maruzat (Y.MTV) 231/53, 10 Rebiülevvel 1320 (17 Haziran 1902).

${ }^{123}$ Neşe Erim, "Osmanlı İmparatorluğunda Kalebentlik Cezası ve Suçların Sınıflandırılması Üzerine Bir Deneme", Osmanlı Araştırmaları IV, Ed. Halil İnalcık, Nejat Göyünç, Heath W. Lowry, İstanbul 1984, s. 83.

${ }^{124}$ Pierce, age. s. 476; Ergene, agm., s. 215-244.

${ }_{125}$ Dror Ze'evi, Müslüman Osmanlı Toplumunda Arzu ve Aşk 1500-1900, Çev. Fethi Aytuna, Kitap Yay., İstanbul 2008, s. 84-91.
} 
düzenlemeler diğer ceza davalarında olduğu gibi cinsel saldırı davalarında da prosedür olarak birtakım değişiklikler yaratmıştır. İddiasını şer’î mahkemede kanıtlayamayan kadınların davalarını nizamiye mahkemesine taşıyarak burada ayrıca görülmesini talep edebilmesi bu değişikliklerden bir tanesidir. Nizamiye mahkemeleri davanın daha derin bir tahkikat sürecinden geçirilmesi, ikincil derece kanıtların kullanılması ve hâkimin takdir yetkisince karar verebilmesinin yollarını açmıştır.

İslam hukukunun ilkeleri ve Tanzimat öncesi uygulamalar cinsel saldırı suçlarının davanın saldırıya maruz kalan tarafından mahkemeye getirildiğini gösterir. Mağdur taraf mahkemeye gitmediği sürece devlet temsilcileri tarafından herhangi bir kamu davasının açılmadığı bilinmektedir. Bu durum cinsel saldırı suçlarının eğer ki saldırgan eşkıyalıkla alakalı bir kişi değilse Tanzimat öncesi dönemde şahıs hukuku çerçevesinde değerlendirildiğini gösterir. Benzer durum cinayet davaları için de geçerlidir. Modern öncesi dönemde "Irz padişahındır." deyiminde ırz kelimesi daha fazla insan onuru ile ilgili bir anlam ifade ederken modernleşme iddialarının belirmesiyle ırz daha çok kadın bedeni üzerinden toplumsal düzeni sağlamanın bir aracı hâline gelmiştir. Geleneksel dönemde mahkemenin taraflara sulh yolunu açık bırakması, evlilik ya da tazminat üzerine bir anlaşma yapıldığı takdirde davanın ortadan kalkmasının yolunu açabilmekteydi. Şer'î mahkemelerin daha az prosedür içeren ve daha düz olan yapısı modern dönem mahkemelerine göre daha pratik davranmalarını sağlayabilmiştir. ${ }^{126}$ $\mathrm{Bu}$ dönemde şahıs hukukundan ayrı olarak kamu davasının görülmemesi araştırmacıları şaşırtacak sayıda cinsel saldırı davasının mahkemeye taşınmış olmasının bir nedeni olarak değerlendirilebilir. Yasal düzenlemelerle tecavüz davalarının kamu davasına dönüşmesi, uzun bürokrasi sürecini beraberinde getirmiş daha fazla sayıda devlet görevlisi davaya müdahil olmuştur. Bu durum modern zaman kadınlarının bu suçun kurbanı olduklarında mahkemeye gitmeye daha fazla çekinmelerinin bir nedeni olarak görülebilir. Modernleşmenin kadın yaşamına inkâr edilemez faydaları olmakla birlikte kamu otoritesinin birey karşısında güçlenmesine yol açan yapısı bazı alanlarda kadınların beklenenin aksine tutumlar geliştirmelerine sebep olmuş görünmektedir.

\section{Kaynakça}

\section{Başbakanlık Osmanlı Arşivi Belgeleri (BOA)}

Bab-ı Âli Evrak Odası (BEO), Dosya: 931, Gömlek: 69777; 31008/233051, 13 Cemaziyelahir 1325 (24 Temmuz 1907).

Irade Divan-ı Ahkâm-ı Adliye, 12/449, 10 Şaban 1290 (3 Ekim 1873).

Meclis-i Valâ (MVL), 950/25, 13 Muharrem 1279 (11 Temmuz 1862); 029/81, 27 Muharrem 1283 (11 Haziran 1866); 1023/54, 6 Receb 1283 (14 Kasım 1866). 990/20, 23 Muharrem 1281 (28 Haziran 1864).

Sadaret Umum Vilayet Evrakı (A. MKT. UM), 392/77, 4 Receb 1276 (27 Ocak 1860).

Taşra Evrakı Bosna Müfettişliği Evrakı (TŞR. BNM) 28/161, 7 Rebiülahir 1281 (8 Eylül 1864).

Teftişat-ı Rumeli Evrakı Jandarma Müşiriyet ve Kumandanlık Evrakı (TFR. I.AS.) 44/4373, 7 Safer 1325 (26 Mart 1907).

Yıldız Mütenevvi Maruzat (Y.MTV) 231/53, 10 Rebiülevvel 1320 (17 Haziran 1902).

\footnotetext{
${ }^{126}$ Şer'̂̂ mahkemelerin şekilden çok öze göre karar vermesi ve bu durumun nizamiye mahkemeleri ile karş1laştırması için bkz. Rubin, Avi; Ottoman Modernity: The Nizamiye Courts In the Late Nineteenth Century, Yayımlanmamış DT, Harward Üniversitesi, 2006.
} 


\section{Matbu, Tetkik Eser ve Makaleler}

Abac1, Nurcan, Bursa Şehri’nde Osmanlı Hukukunun Uygulanması (17. Yüzyll), T.C. Kültür Bakanlığı Yay./2778 Yayımlar Dairesi Başkanlığı Kültür Eserleri Dizisi/328, Ankara 2001.

Abdurrahman Şeref, Tarih Musahabeleri, Sadeleştiren: Enver Karay, Kültür ve Turizm Bakanlığı Yay., Ankara 1985.

Abu-Lughad, Lila, "Honor and Sentiments of Loss in a Bedouin Societiy", American Ethnologist, 12/2, May1s 1985, ss. 245-261.

Ahmet Lütfi, Mir'at-ı Adalet yahut Tarihçe-i Adliye-i Devlet-i Aliyye, Matbaa-i Nişan Berberyan, İstanbul 1304.

Araz, Yahya, "Cariyeler, Efendiler ve Pusuda Bekleyenler: Osmanlı İstanbul'unda Hamile ve Çocuk Annesi Cariyeler Üzerine Düşünceler (1790-1880)”, Kebikeç, 37, 2014, s. 233260.

Araz, Yahya, 16. Yüzyıldan 19. Yüzyıl Başlarına Osmanlı Toplumunda Çocuk Olmak, Kitap Yay., İstanbul 2013.

Avc1, İsmail, “Osmanlılarda Zina Suçu ve Cezası”, Türkler, C. X, ss. 149-164.

Avc1, Mustafa, Osmanlı Hukukunda Suçlar ve Cezalar, Gökkubbe Yay., İstanbul 2004.

Aykut, Ebru, "Osmanlı Mahkemelerinde Şüpheli Zehirlenme Vakaları, Adlî Tıp Pratikleri ve Tıbbi Deliller”, Tarih ve Toplum Yeni Yaklaşımlar, 17, Bahar 2014, ss. 7-36.

Baer, Marc David, At Meydanında Ölüm 17. Yüzyıl İstanbul'unda Toplumsal Cinsiyet, Hoşgörü ve İhtida, Çev. Pınar Yanardağ, Koç Üniversitesi Yay., İstanbul 2016.

Balsoy, Gülhan Erkaya, Kahraman Doktor İhtiyar Acuzeye Karşı Geç Osmanlı Doğum Politikalarl, Can Yay., İstanbul 2015.

Çoklar, Iş1, Kadına Yönelik Cinsel Şiddetin Meşrulaştırılması ve Tecavüze İlişsin Tutumlar, Yayımlanmamış Yüksek Lisans Tezi, Ege Üniversitesi, SBE, İzmir 2007.

Deal, Roger A., Namus Cinayetleri Sarhoş Kavgaları II. Abdülhamid Döneminde Şiddet, Çev. Zeynep Rona, Kitap Yay., İstanbul 2017.

Debbağzade Numan Efendi, Tuhfetu's-Sukuk, Darü’t-Tıbaati'l-Âliye, İstanbul 1259.

Düstur, I. Tertip, C. I, Matbaa-i Âmire, İstanbul 1289.

Düzdağ, M. Ertuğrul, Şeyhülislâm Ebssuud Efendi'nin Fetvalarına Göre Kanuni Devrin Osmanlı Hayatı, Kap1 Yay., İstanbul 2012.

Ergene, Boğaç A., "Why Did Ümmü Gülsüm G oto Court? Ottoman Legal Practice between History and Antropology", Islamic Law and Society, 17, 2010, s. 215-244.

Erim, Neşe, "Osmanlı İmparatorluğunda Kalebentlik Cezası ve Suçların Sınıflandırılması Üzerine Bir Deneme”, Osmanlı Araştırmaları IV, Ed. Halil İnalcık, Nejat Göyünç, Heath W. Lowry, İstanbul 1984, ss. 79-88.

Fuchs, Rachel G., Leslie Page Moch, "Pregnant Single and Far From Home: Migrant Women in Nineteenth-Century Paris”, The American Historical Reiew, 95/4, 1996, ss. 1007-1031.

Garnett, Lucy M. J., The Women of Turkey and Their Folklore, London: David Nutt, 1890.

Ginio, Eyal, "Women, Domestic Violence and Breaking Silince: The Evidence of the Şeriat Court of Eighteenth-Century Salonica”,Mélanges en I'Honneur du Prof. Dr. Suraiya 
Faroqhi, ed. Abdeljelil Temimi, Publications de la Fondation Temimi pour la Recherche Scientifique et I'Information, Tunus 2008, ss. 153-168.

Halil Rıfat, Külliyat-ı Şerh-i Ceza, Mihran Matbaası, İstanbul 1312.

Heyd, Uriel, Studies in Old Ottoman Criminal Law, Clarendon Press, Oxford 1973.

Hill, Julis R. Ruff, Erken Modern Avrupa'da Şiddet (1500-1800), Çev. Didem Türkoğlu, Boğaziçi Üniversitesi Yay., İstanbul 2011.

Hökelek, Hayati, “’”Irz”, Diyanet İslam Ansiklopedisi, C. 19, 1999, ss. 133-134.

Hüseyin Galip, Kamus-i Hukuk, Cemal Efendi Matbaası, İstanbul 1305.

Imber, Colin, Studies in Ottoman History and Law, The Isıs Press, İstanbul 1996.

Imber, Colin, Şeriattan Kanuna Ebussuud ve Osmanlı'da İslami Hukuk, Çev. Murteza Bedir, Tarih Vakfi Yurt Yay., İstanbul 2004.

Işık, Zekeriya, "Osmanlı İmparatorluğu'nda Kamusal Alanda Cinsiyet ve Toplumsal Cinsiyet Kimliğiyle Kadın (1839-1900): Çorum Şer'iyye Mahkemesi Örneği”, bilig Türk Dünyası Sosyal Bilimler Dergisi, S. 85, ss. 25-56.

İpşirli, Mehmet, "XVI. Yüzyılın İkinci Yarısında Kürek Cezası İle İlgili Hükümler”, İstanbul Üniversitesi Edebiyat Fakültesi Tarih Enstitüsü Dergisi Prof. Tayyip Gökbilgin Hatıra Saylsl, S. 12, s. 203-248.

Kandiyoti, Deniz, Cariyeler Bacılar Yurttaşlar Kimlikler ve Toplumsal Dönüşümler, Metis Yay., İstanbul 2015.

Karakışla, Yavuz Selim, Osmanlı Hanımları ve Hizmetçi Kadınlar (1869-1927), Akıl Fikir Yay., İstanbul 2014.

Kaya, Süleyman, "Mahkeme Kayıtlarının Kılavuzu: Sakk Mecmuaları", Türkiye Araştırmaları Literatür Dergisi, C. 3, S. 5, 2005, ss. 379-416.

Kevorkian, Nadera Shalhoub, "Tecavüzün Kültürel Bir Tanımına Doğru: Filistin Toplumunda Tecavüz Mağdurlarıyla Çalışırken Karşılaşılan İkilemler”, Müslüman Toplumlarda Kadın ve Cinsellik, Der. Pınar İlkkaracan, İletişim Yay., İstanbul 2015, ss. 207-243.

Koğacıŏglu, Dicle, "Gelenek Söylemleri ve İktidarın Doğallaşması: Namus Cinayetleri Örneği”, Cogito, S. 58, 2009, ss. 350-384.

Konan, Belkıs, “Osmanlı Hukukunda Tecavüz Suçu”, OTAM, 29, Bahar 2011, ss. 149-172.

Kurt, Abdurrahman, Bursa Sicillerine Göre Osmanlı Ailesi(1839-1876) Sosyo-Ekonomik Yapı Gelenek ve Görenekler, Sentez Yay., Ankara 2013.

Maksudyan, Nazan, "Foster-Daughter or Servant, Charity or Abuse: Beslemes in the Late Ottoman Empire”, Journal of Historical Sociology, 21/4, Aralık 2008, ss. 488-512.

Marcus, Abraham, "Privacy in Eighteenth Century Aleppo: The Limits of Cultural Ideals", IJMES, C. 18, S. 2, May1s 1986, ss. 165-183.

Meclis-i Mebusan Zabit Ceridesi, Devre:1, C.II, TBMM Basımevi, Ankara, 1982.

Menekşe, Ömer, “Osmanlı'da Zina Cezası Olarak Recm”, Marife, Yı1 3, S. 2, Güz 2003, ss. 7 18.

Miller, Ruth A., Osmanlı'dan Cumhuriyet'e Günah ve Suç Fıkıhtan Faşizme, Çev. Hamdi Çilingir, Ufuk Yay., İstanbul 2013.

Mutaf, Abdülmecit, "Teorik ve Pratik Olarak Osmanlı'da Recm Cezası Bazı Batı Anadolu Şehirlerindeki Uygulamalar”, Turkish Studies, $3 / 4$ Yaz 2008, ss. 573-597. 
Osmanoğlu, Cihan, "Klasik Dönem Osmanlı Hukukunda Zina Suçu ve Cezası”, İ̈HFM, C. 66, S. 1, ss. 109-178.

Özbay, Ferhunde, "Evlerde El Kızları: Cariyeler, Evlatlıklar, Gelinler", Feminist Tarih Yazımında Sinıf ve Cinsiyet, Ed. Leonore Davidoff, İletişim Yay., İstanbul 2016.

Özdemir, Omca, Bir İktidar Tekniği Olarak Kadına Yönelik Tecavüz Tehdidi, Yayımlanmamış Yüksek Lisans Tezi, Ankara Üniversitesi, SBE, Ankara 2010.

Öztop, Fatih, "Suç Cetvellerine Göre Osmanlı Devleti'nde 'Kız Kaçırmak' Suçu: Aydın Vilayeti Örneği (1908-1916)”, TiDSAD, S. 2, Mart 2015, ss. 288-298.

Pierce, Leslie, "Ekberiyet, Cinsellik ve Toplum Düzeni: Modern Dönemin Başlangıcında Toplumsal Cinsiyetle İlgili Osmanlı Söz Dağarcığı”, Modernleşmenin Eşiğinde Osmanlı Kadınları, Ed. Madeline C. Zilfi, Çev. Necmiye Alpay, Tarih Vakfı Yurt Yay., İstanbul 2000, s. 166-193.

Pierce, Leslie, Ahlak Oyunlart 1540-1541 Osmanlı'da Ayıntab Mahkemesi ve Toplumsal Cinsiyet, Çev. Ülkü Tansel, Tarih Vakfı Yurt Yay., İstanbul 2005.

Rubin, Avi; Ottoman Modernity: The Nizamiye Courts In the Late Nineteenth Century, Yayımlanmamış DT, Harward Üniversitesi, 2006.

Schick, Irvin Cemil, Bedeni, Toplumu, Kâinatı Yazmak İslam, Cinsiyet ve Kültür Üzerine, Çev. Pelin Tünaydın, İletişim Yay., İstanbul 2014.

Scully, Diana, Cinsel Şiddeti Anlamak Tutuklu Tecavüzcü Erkekler Üzerine Bir İnceleme, Çev. Şirin Tekeli, Laleper Aytek, Metis Yay., İstanbul 2013.

Sonbol, Amira, “Osmanlı Misır'ı ve Modern Mısır'da Tecavüz ve Hukuk”, Modernleşmenin Eşiğinde Osmanlı Kadınları, Ed. Madeline Zilfi, Çev. Necmiye Alpay, Tarih Vakfı Yurt Yay., İstanbul 2010, ss. 211-230.

Tenger, Feyza, İslam Hukukunda Hâkimin Takdir Yetkisi Bağlamında Kendi Bilgisiyle Hüküm Vermesi, Yayımlanmamış Yüksek Lisans Tezi, Ankara Üniversitesi, 2006.

Tok, Özen, "Kadı Sicilleri Işs̆ğında Osmanlı Şehrindeki Mahalleden İhraç Kararlarında Mahalle Ahalisinin Rolü (XVII. ve XVIII. Yüzyıllarda Kayseri Örneği”", SBE Dergisi, S. 18, 2005, ss. $155-173$.

Toledano, Ehud R., Suskun ve Yokmuşcasına İslam Ortadoğu'sunda Kölelik Bağları, Çev. Hakan Erdem, İstanbul Bilgi Üniversitesi Yay., İstanbul 2010.

Tuğ, Başak, "Gendered Subjects in Ottoman Costitutional Agreements, c.a. 1740-1860", European Journal of Turkish Studies, S. 18, 2014, ss. 1-22.

Tuğ, Başak, Müslüman Osmanlı Toplumunda Arzu ve Aşk 1500-1900, Çev. Fethi Aytuna, Kitap Yay., İstanbul 2008.

Tuğ, Başak, Politics of Honor: The Institutional and Social Frontiers of "Illicit" Sex in MidEighteenth Century Ottoman Anatolia Yayımlanmamış DT, New York Üniversitesi, 2009.

Yağcı, Zübeyde G., "Osmanlı Kanunnamelerinde Suç ve Ceza",Tanzimat Öncesi Osmanlı Toplumunda Cinsiyet, Mahremiyet ve Sosyal Hayat, Ed. Miyase Koyuncu Kaya, Bedriye Yılmaz, Türkiye Diyanet Vakfı Yay., Ankara 2018, ss. 414-445.

Yağcı, Zübeyde G., "Osmanlı Taşrasında Kadınlara Yönelik Cinsel Suçlarda Adalet Arama Geleneği”, Kadın Araştırmaları Dergisi, 6/2, Aralık 2005, ss.51-81. 
Yılmaz, Fikret, "XVI. Yüzyıl Osmanlı Toplumunda Mahremiyetin Sınırlarına Dair", Toplum ve Bilim, S. 83, Kış 1999/2000, ss. 92-110.

Yılmaz, Fikret, "Zina ve Fuhuş Arasında Kalanlar Fahişe, Subaşıya Karşı”, Toplumsal Tarih, S. 220, Nisan 2012, ss. 22-31.

Ze'evi, Dror, “The Use of Ottoman Shari'a Court Records as a Source of Middle Eastern Social History: A Reappraisal”, Islamic Law and Society, 5/1, 1998, ss. 35-56.

Ze'evi, Dror, "Women in 17th Century Jerusalem: Western and Indigenous Perspectives", Internatinal Journal of Middle East Studies (IJMES), C. 27, S. 2, Mayıs 1995, ss. 157173.

Zilfi, Madeline C., Osmanlı Imparatorluğunda Kölelik ve Kadınlar (1700-1840), Çev. Ebru Kılıç, İş Bankası Yay., 2018. 
Ek-1: BOA, MVL, 950/25, 4 Zilkade 1278 Petkane, Rıza ve Hristo'nun Pazarcık Meclisindeki Istintak Kayltları

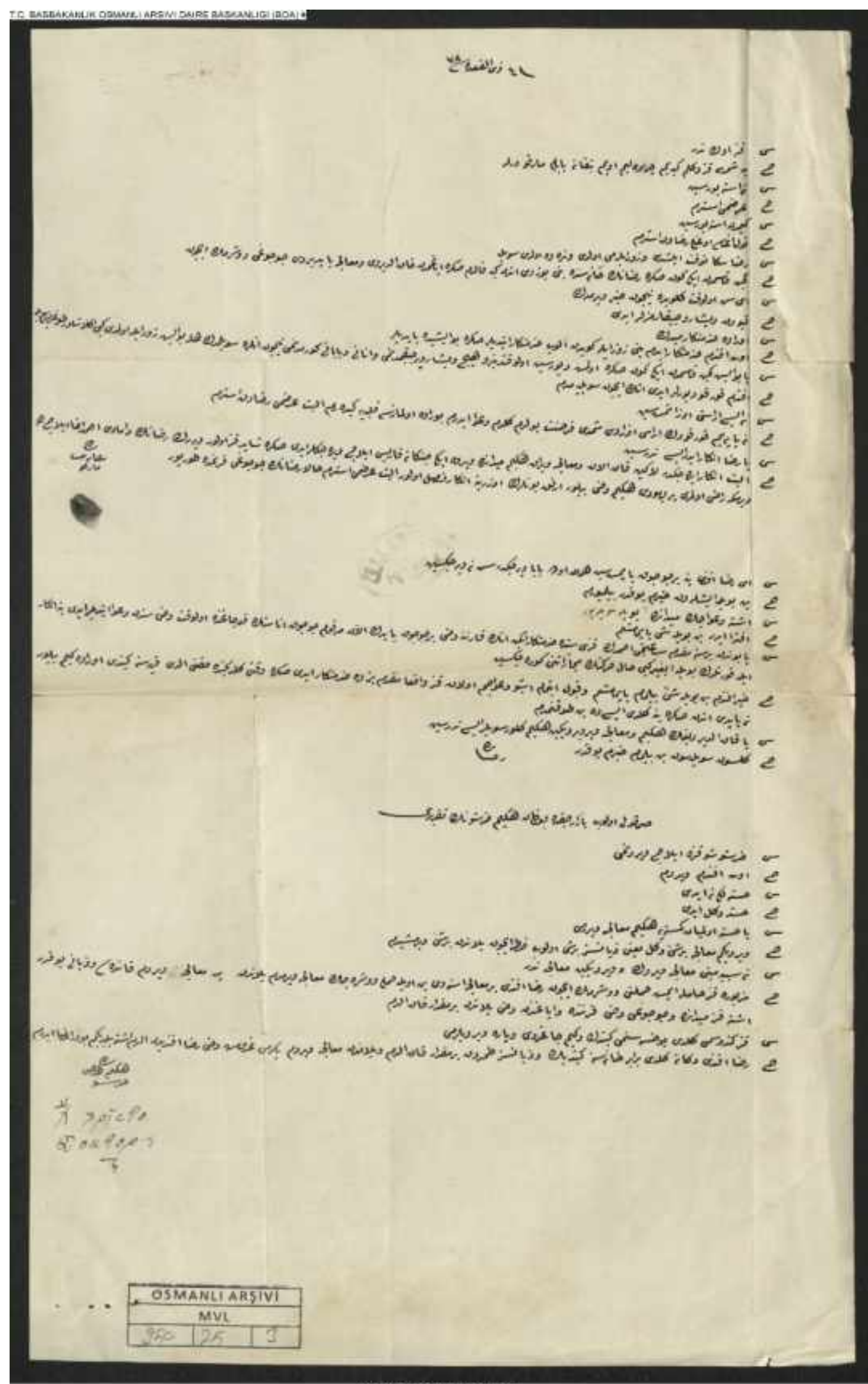

MVL $00950,00025,003$ 
Ek-2: BOA, MVL 950/25 15 Petkane ve Rıza'nın Filibe Meclisindeki İstintak Kaydı

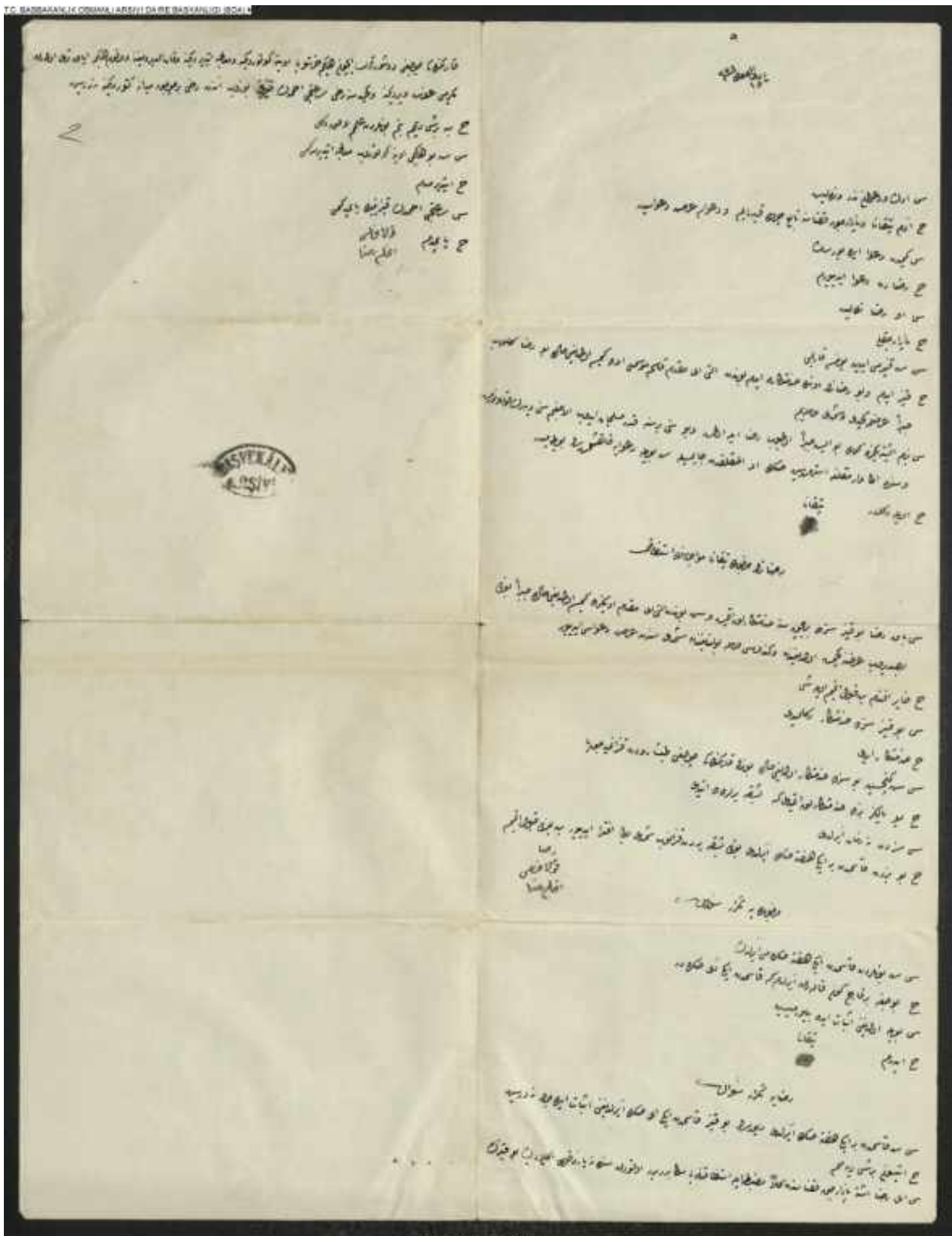

MVL 0095000025001 